\title{
WHAT FILMS WE MAY WATCH: VIDEOTAPE DISTRIBUTION AND THE FIRST AMENDMENT
}

\author{
Karl A. Groskaufmanis $\dagger$
}

If the First Amendment means anything, it means that a State has no business telling a man, sitting alone in his own house, what books he may read or what films he may watch. -Stanley v. Georgia, 394 U.S. 557, 565 (1969).

The video cassette recorder ("VCR") - the electronic boon of the decade-presents an important challenge for the first amendment. The VCR's importance is underscored by its explosive growth in popularity. A novelty in $1980,{ }^{1}$ the VCR now is found in 37 million homes. $^{2}$ Presently devoted largely to entertainment use, the VGR's niche is expanding to include commercial and political functions. The video cassette is an integral information source for millions of viewers. The legal challenge is to adapt constitutional protection to this new form of expression. ${ }^{3}$

The VGR's introduction coincides with renewed pressure for con-

† B.S. 1984, Cornell University; LL.B. 1987, University of Toronto; J.D. Candidate 1988, University of Pennsylvania.

1 In 1980, VCRs were found in one percent of American homes. See Stander, The Impact of the VCR on Broadcast Television, in Video CaSSETtes: Production, Distribution, AND PROgRamming For the VGR MARKetplace 481, 483 (1985) [hereinafter VIDEO CASSETTES].

${ }^{2}$ See Nordheimer, New Issue as VCR's Expand: Violent Films and the Young, N.Y. Times, May 18, 1987, at A1, col. 3, B9, col. 3. Half the nation's television households were expected to have a VCR by the end of 1987. See Slow Motion for VCR's, N.Y. Times, May 24, 1987, § III, at 1, col. 1 [hereinafter Slow Motion]. Sales are projected to level off at three-quarters of American "color TV households." See Bernstein \& Lorber, The VCR Marketplace: Production, in Video CasseTtes, supra note 1 , at $15,20$.

3 This Comment will consider the issue of content regulation with respect to videotapes and VCR technology. This will not include a consideration of the copyright issue raised by the use of VCR technology. See Sony Corp. of Am. v. Universal City Studios, Inc., 464 U.S. 417, 456 (1984) (public sale of VCRs does not constitute contributory copyright infringement); see also Lloyd \& Mayeda, Copyright Fair Use, the First Amendment, and New Communications Technologies: The Impact of Betamax, 38 FED. COMM. L.J. 59, 101 (1986) (concluding that "in the absence of a clear showing of dramatic financial loss to copyright holders, the courts are likely to insure that the consuming public receives the benefits of expanded information access made possible by new communications technologies"). 
tent regulation of the electronic media. There are two chief manifestations of this pressure. The Report of the Attorney General's Commission on Pornography ("Meese Commission") 4 chronicles an agenda for controlling the availability of sexually explicit material. Concurrently, radical feminist theory provides a new justification for such control. Because pornography constitutes an assault on women's rights, the theory holds, its restriction amounts to a form of self defense. Consequently, sexually oriented videos ${ }^{8}$ have become the focus of a new generation of censors. The video cassette's evolution as the medium of choice for nonstill sexual material prompts the demands for scrutiny that usually accompany new entertainment technology. ${ }^{6}$

The VGR is part of a second development, the technological change undermining traditional justifications for content regulation of the electronic media. Much of this regulation is rationalized on the premise that broadcasters occupy part of a limited spectrum and easily can become a pervasive intrusion into the home. Cable television renders these concerns moot. Its unlimited spectrum eliminates the scarcity rationale behind the fairness doctrine; consumer control over the medium makes inapplicable the reasoning that justified a stricter standard of review for nonobscene "indecent" broadcasts. The VCR takes the change one step further. The recorder creates an autonomous television unit without the use of publicly franchised lines or the airwaves. There is no government or corporate gatekeeper; the new technology already features ideas and events that "could not previously penetrate through the wall of existing intermediaries between creators and audiences." In that sense, the characteristics of VCR speech resemble more closely the print media than broadcasting. The VCR has the potential, the Federal Communications Commission ("FGC") concludes, "to become the 'elec-

4 U.S. Department of Justice, Attorney General's Commission on PorNOGRAPHY, Final RePORT (1986) [hereinafter Final REPORT].

5 The restrictive efforts often are aimed primarily at X-rated films in the genre of "Debbie Does Dallas"-films that are available through commercial channels and form the traditional fare of adult theaters. This Comment argues that such material, if produced by consenting adults, should be constitutionally protected for VCR use. This argument does not extend to the use of VCR technology as a new form of child abuse. See, e.g., United States v. Freeman, 808 F.2d 1290, 1291, 1293 (8th Cir.) (upholding conviction of defendants under the Child Protection Act of 1984, 18 U.S.C. $\S 2251-55$ (1982 \& Supp. III 1985) for production of child pornography), cert. denied, $107 \mathrm{~S}$. Ct. 1384 (1987).

- The introduction of motion pictures, radio, and television each met initially with fear of the medium's potential for harm and with subsequent rationales for government control. See Lively, Fear and the Media: A First Amendment Horror Show, 69 MINN. L. REV. 1071, 1074-77 (1985).

${ }_{7}$ Price, The Video Revolution, Wall St. J., March 5, 1984, at 28, col. 1, 28, col. 
tronic handbill[]' or indeed even the electronic newspaper of the future." Technological change blurs the distinctions that produced constitutional standards that vary with the media. Without judicial articulation of a first amendment standard for VCR technology, the daily exercise of expression rights remains subject to the whims of local regulation. Because the VCR medium parallels the print media closely, it warrants the same level of constitutional protection. Arguments currently favoring restriction are particularly weak in the context of VCR use. This use, even in its infancy, has turned a monopolistic medium into a widely varied marketplace of ideas. The first amendment's challenge is to remain relevant in this new marketplace.

\section{Reviving Content Regulation}

\section{A. A History of Obscenity}

$\mathrm{X}$-rated video cassettes mark the latest chapter in the muddled law of obscenity regulation. ${ }^{2}$ This regulation is largely a product of the last century. ${ }^{10}$ Pressured by late nineteenth-century moral crusaders, courts

${ }^{B}$ Inquiry into Section 73.1910 of the Commission's Rules and Regulations Concerning the General Fairness Doctrine Obligations of Broadcast Licensees, 102 F.C.C.2d 143, 214 (1985) [hereinafter Inquiry].

- Obscenity law is mired in subjectivity. Justice Stewart captured this uncertainty when he conceded that while he was unable to define obscenity, "I know it when I see it." Jacobellis v. Ohio, 378 U.S. 184, 197 (1964) (Stewart, J., concurring). The problem has plagued this regulation since its inception. See Commonwealth v. Landis, 8 Phila. (Legal Intelligencer) 453, 453 (1870) ("Obscenity is determined by the common sense and feelings of mankind, and not by the skill of the learned."). The Supreme Court has not provided a consistent interpretation; thirteen decisions between 1957 and 1968 featured 54 separate opinions. See D. Pember, Mass Media Law 350 (2d ed. 1981).

10 All the American colonies made blasphemy a crime by statute, "but sexual materials not having an antireligious aspect were left generally untouched." $F$. SchaUer, The Law of OBscenITy 8 (1976); see also United States v. 12 200-Ft. Reels of Super 8mm. Film, 413 U.S. 123 (1973):

The first amendment was the product of a robust, not a prudish, age. . . .

This was the age when Benjamin Franklin wrote his "Advice to a Young Man in Choosing a Mistress .... W" When the United States became a nation, none of the fathers of the country were any more concerned than Franklin with the question of pornography. John Quincy Adams had a strongly puritanical bent for a man of his literary interests, and even he wrote of Tom Jones that it was " "one of the best novels in the language." ... The Anthony Comstocks, the Thomas Bowdlers and Victorian hypocrisy-the predecessors of our present obscenity laws-had yet to come upon the stage.

Id. at 132-22 (Douglas, J., dissenting) (citations omitted). Vermont passed the nation's first obscenity statute in 1821, providing that "if any persons shall hereafter print, publish or vend any lewd or obscene book, picture or print, on conviction . . . [they] shall be sentenced to pay a fine not exceeding two hundred dollars." 1824 Vt. Laws ch. 
embraced the obscenity standard set out in Regina $v$. Hicklin. ${ }^{11}$ This definition focuses on whether the material in question would tend to "deprave and corrupt those whose minds are open to such immoral influences, and into whose hands a publication of this sort may fall."12 That standard shaped obscenity regulation until the Court's modern effort to craft a workable guideline. ${ }^{13}$ Facing the obscenity issue directly in Roth $v$. United States, ${ }^{14}$ the Court determined that the first amendment's history did not compel protection of obscenity. ${ }^{15}$ The contemporary yardstick of obscenity was enunciated in a 1973 ruling, Miller $v$. California..$^{16}$ Miller requires the court to consider:

(a) whether "the average person, applying contemporary community standards" would find that the work, taken as a whole, appeals to the prurient interest;

(b) whether the work depicts or describes, in a patently offensive way, sexual conduct specifically defined by the applicable state law; and

(c) whether the work, taken as a whole, lacks serious literary, artistic, political, or scientific value. ${ }^{17}$

While the Miller test provides a measure against which obscenity is assessed, ${ }^{18}$ there is little agreement on what the measure means. ${ }^{18} \mathrm{Ob}$ scenity regulation is most likely to be endorsed when it "protect[s] children and . . . the sensibilities of unwilling viewers." ${ }^{20}$ Given its uncer-

XXXII, no. $1, \S 23$, cited in F. Schauer, supra, at 10 . Although there was a proliferation of such legislation prior to the Civil War, there were few prosecutions. $I d$.

113 L.R.-Q.B. 359 (1868).

12 Id. at 369; see also United States v. Kennerley, 209 F. 119, 120 (S.D.N.Y. 1913); MacFadden v. United States, 165 F. 51, 52 (3d Cir. 1908).

is See Chaplinsky v. New Hampshire, 315 U.S. 568, 571-72 (1942) (defining its "fighting words" doctrine, the Court included the "lewd and obscene" in classes of speech that warrant no protection).

14354 U.S. 476 (1957).

1s See $i d$. at 485 ("[O]bscenity is not within the area of constitutionally protected speech or press.").

16413 U.S. 15 (1973).

${ }^{17} I d$. at 24 (citations omitted).

18 See New York v. Ferber, 458 U.S. 747, 755 (1982) ("Over the past decade, we have adhered to the guidelines expressed in Miller, which subsequently has been followed in the regulatory schemes of most States." (footnotes omitted)). See Portland v. Jacobsky, 12 Media. L. Rep. (BNA) 1433, 1434-45 (Me. Sup. Jud. Ct. 1985) (Maine obscenity statute is not overbroad under the Miller test).

${ }_{19}$ See Pope v. Illinois, 107 S. Ct. 1918, 1923 (1987) (Scalia, J., concurring) ("[I]t is quite impossible to come to an objective assessment of (at least) literary or artistic value, there being many accomplished people who have found literature in Dada, and art in the replication of a soup can. . . . All of today's opinions, I suggest, display the need for reexamination of Miller.").

${ }^{20} I d$. at 1930 (Stevens, J., dissenting). 
tainty, this beneficent use of the Miller standard is most likely to garner judicial approval. The Court remains sympathetic to obscenity regulation aimed at protecting community standards. In Miller's companion case, Paris Adult Theater $I$ v. Slaton, ${ }^{21}$ it recognized the government interest in this protection- "the total community environment, the tone of commerce in the great city centers and, possibly, the public safety itself." 22 To allow even a discrete public display of obscene material grants an individual the right to " affect the world about the rest of us, and to impinge on other privacies." 23 On the premise that municipal efforts "to preserve the quality of urban life . . . must be accorded high respect," sion of and the concentration of adult movie theaters. ${ }^{25}$ These zoning provisions are justified by the deleterious "secondary effects of such theaters on the surrounding community." ${ }^{26}$ In City of Renton $v$. Playtime Theatres, Inc. ${ }^{27}$ Justice Rehnquist characterized the restriction of theater location as "preserving the quality of life in the community at large." ${ }^{28}$ Over an objection that this content-based regulation represents a "drastic departure" from first amendment principles, ${ }^{29}$ the Miller test has supported regulation aimed at preserving community standards.

There is greater unanimity in support of regulation limiting minors' access to sexually-explicit materials. Writing for a unanimous court in Ginsberg $v$. New York, ${ }^{30}$ Justice Brennan noted that even in the invasion of protected freedoms, "the power of the state to control the conduct of children reaches beyond the scope of its authority over

21413 U.S. 49 (1973).

22 Id. at 58.

${ }^{23}$ Id. at 59 (quoting Bickel, On Pornography: Dissenting and Concurring Opinions, 22 PUBLIC INTEREST, Winter 1971, at 25, 25-26 (emphasis omitted)).

${ }_{24}$ Young v. American Mini Theaters, Inc., 427 U.S. 50, 71 (1976) (Stevens, J., plurality opinion).

${ }^{25}$ Compare Young, 427 U.S. at 58-61 (upholding Detroit "Anti-Skid Row" ordinance's prohibition of location of adult theaters within 1,000 feet of any two other "regulated uses" or 500 feet of a residential area) with City of Renton v. Playtime Theatres, Inc., $106 \mathrm{~S}$. Ct. 925, 931 (1986) (upholding municipal ordinance effectively limiting adult movie theaters to an area constituting five percent of city space).

${ }^{28}$ Renton, 106 S. Ct. at 929; see also Young, 427 U.S. at 54 n.6 (Detroit's ordinance grouped adult theaters with "some uses which, because of their very nature, are recognized as having . . . a deleterious effect upon the adjacent areas. Special regulation of these uses is necessary to insure that these adverse effects will not contribute to the blighting or downgrading of the surrounding neighborhood.").

27106 S. Ct. 925 (1986).

${ }^{28} I d$. at 932 .

${ }^{29}$ Young, 427 U.S. at 84 (Stewart, J., dissenting); see also Renton, 106 S. Ct. at 937 (Brennan, J., dissenting) (noting a paucity of evidence that adult theaters will lead to the "secondary effects" on which the majority bases its decision).

so 390 U.S. 629 (1968). 
adults'." The state's "independent interest in the well-being of its youth"32 provided a sufficient basis in Ginsberg for the statutory proscription of the sale of a nonobscene "girlie" magazine to a sixteenyear-old patron. ${ }^{33}$ In a 1982 decision, the Court stated that this interest entitled the states to "greater leeway in the regulation of pornographic depictions of children." 34 The Court has been sympathetic to the exclusion of children from the production and display of sexual material even when the material falls short of the obscenity standard.

This concern is evident in the limited prosecutorial activity the Meese Commission deemed "striking underenforcement."35 Currently, federal enforcement focuses primarily on child pornography. ${ }^{36}$ While the Commission took heart in local initiatives, the investigation found such prosecutorial diligence to be the exception. ${ }^{37}$ The Commissioners reported a reluctance to proceed with obscenity actions. Federal prosecutions were rare in districts encompassing the major production centers for most explicit material. ${ }^{38}$ In effect, there was "no [federal] prosecution of [printed] materials now ....."39 Prosecutors were recalcitrant in response to demands for stepped up enforcement; ${ }^{40}$ the Commission concluded that the Department of Justice obscenity policy and guidelines "are not being implemented by the United States Attorneys." 11 The complexity and uncertainty of the law in obscenity cases

31 Id. at 638 (quoting Prince v. Massachusetts, 321 U.S. 158, 170 (1944)).

${ }^{32} I d$. at 640.

${ }^{33}$ See id. at 631.

${ }^{34}$ New York v. Ferber, 458 U.S. 747, 756 (1982). The Court contrasted the compelling state interests in protecting the individual child's welfare and in reducing child abuse against the modest, "if not de minimis" value of the speech. Id. at 756-64.

3s 1 FINAL REPORT, supra note 4, at 367.

se See id. The emphasis on child pornography to the exclusion of adult obscenity is apparent in federal statistics. From 1978 to February, 1986, 255 persons were indicted for child pornography law violations. This resulted in 215 convictions. In the same time period, there were 100 indictments leading to 71 convictions for other obscenity law violations. Id. at 507 n.200.

${ }_{37}$ See id. at 365 (In Cincinnati and Atlanta, "vigorous investigation, vigorous prosecution, and stringent sentencing" have substantially diminished the availability of obscene material.); see also Davis, FCC Chief Shifts Obscenity View as He Seeks Job Reappointment, Wall St. J., Dec. 1, 1986, at 44, col. 1, 44, col. 1 (FCC Chairman taking more restrictive view to placate media watch organizations).

s8 From May 1, 1984 to July, 1985 there were no federal prosecutions in the Southern District of New York (Manhattan) and the Central District of California (Los Angeles). See 1 Final REPORT, supra note 4, at 504.

s9 Id. at 384 .

40 On October 4, 1982, Attorney General William French Smith sent a memorandum to all U.S. Attorneys, calling for aggressive prosecution of obscenity cases. "Despite this directive ... not a single indictment alleging a violation of federal obscenity laws was returned in 1983 in any district in the United States." Id. at 501.

41 Id. at 503. 
contribute to the underenforcement. ${ }^{42}$

\section{B. The Current Mood}

\section{The Meese Commission}

The Meese Commission seeks to reshape this reality through greater content regulation. Concern that technological advances altered pornography was one impetus for the Meese Commission's formation. ${ }^{43}$ Innovations "such as cable television and video cassette recorders" make pornography "available at home to anyone-regardless of age-at the mere touch of a button." 44 The Commissioners were charged with a search for solutions to problems associated with pornography. The year-long investigation concluded that greater regulation is needed because, more than at any other time, "we live in a society unquestionably pervaded by sexual explicitness." 45

The Commission was unequivocal in its conclusion that this proliferation is harmful. At the very least, the Commission concluded that the "predominant" use of "standard pornography . . . is as a masturbatory aid." 46 Pornography's deleterious effects were scaled according to content. The Commission's review of social science literature led to the "unanimous" conclusion that substantial exposure to sexually violent material "bears a causal relationship to antisocial acts of sexual violence." 47 Exposure to nonviolent "degrading"48 material leads to "effects similar to although not as extensive as that involved with violent material."49 The Commission "disagreed substantially" about the impact of nonviolent, nondegrading material depicting "fully willing par-

12 See id. at 519. A prosecutor engaged in prosecuting distributors of obscene video cassettes in Maricopa County, Arizona, notes that even under the best of circumstances, "it's very, very hard to get a conviction in obscenity cases." Lindsey, Outlets That Offer Explicit Sex Tapes Facing Prosecution, N.Y. Times, June 3, 1985, at A1, col. 1, B14, col. 3 .

43 See 1 Final RePORT, supra note 4, at 200, 226.

14 Department of Justice Press Release (May 20, 1985), quoted in Lynn, "Civil Rights" Ordinances and the Attorney General's Commission: New Developments in Pornography Regulation, 21 HARv. C.R.-C.L. L. REv. 27, 28 (1986).

41 Final RePORT, supra note 4, at 277.

16 Id. at 266.

47 Id. at 326. The impact of such material, the Commission concludes, does not vary with the extent of sexual explicitness, "so long as the violence is presented in an undeniably sexual context." Id. at 328.

48 "Degrading" material involves nonviolent portrayal of people, typically women, "as existing solely for the sexual satisfaction of others . . . in decidedly subordinate roles." The term links the characteristics of subordination, domination and humiliation. Id. at 331.

$40 \mathrm{Id}$. at 330.

so Id. at 336 . 
ticipants occupying substantially equal roles."51 With this "pure" sex," ${ }^{\prime \prime 2}$ the Commission's consensus was that the totality of social science evidence "is slightly against" the hypothesis that the material is conducive to sexual violence. ${ }^{53}$ In sum, the Commission concluded that the nature of pornography had changed since $1970,{ }^{54}$ when a predecessor commission found no link between sexually explicit material and antisocial behavior. ${ }^{58}$ Both the nature and the availability of the risk had changed.

The Commission advocated greater judicial scrutiny of this changed market. The Commissioners reaffirmed Miller's requirement of an "admittedly low threshold of cognitive appeal."ss Their report concluded, however, that much available hard-core pornography clearly falls below that threshold. ${ }^{57}$ For such material, the Commission endorsed renewed federal and local enforcement of obscenity statutes ${ }^{88}$ and more stringent penalties. ${ }^{59}$ Implementation of these recommendations would signal a new era of content regulation.

\section{The Radical Feminist Response}

The radical feminist "civil rights" movement, a hybrid of the 1980 s, is a new factor in the obscenity debate. Radical feminist theory shifts the focus of obscenity regulation. Rather than protection of the community's moral fiber, the theory focuses on protection from physical harm as a justification for pornography regulation. ${ }^{60}$ Linking physical

51 Id. at 335 .

${ }_{62}$ Id. at 336 .

${ }^{53}$ Id. at $337-38$.

54 See id. at 225 ("[A]ll of us have taken issue with at least some of the earlier Commission's conclusions."); see also supra note 45 and accompanying text.

so See Commission on Obscenity and Pornography, The Report of the CoMmission ON OBSCENITY AND PORNOGRAPHY 27 (1970).

s6 1 Final REPORT, supra note 4, at 264.

${ }^{87}$ See id. at 264-65.

s8 Recommendation 11: "THE ATTORNEY GENERAL SHOULD DIRECT THE UNITED STATES ATTORNEYS TO EXAMINE THE OBSCENITY PROBLEM IN THEIR RESPECTIVE DISTRICTS, IDENTIFY OFFENDERS, INITIATE INVESTIGATIONS, AND COMMENCE PROSECUTION WITHOUT FURTHER DELAY." Id. at 435-36. Recommendation 20: "STATE AND LOCAL PROSECUTORS SHOULD ALLOCATE SUFFICIENT RESOURCES TO PROSEGUTE OBSCENITY CASES." Id. at 438.

so Recommendation 8: "STATE LEGISLATURES SHOULD AMEND, IF NEGESSARY, OBSCENITY STATUTES TO ELIMINATE MISDEMEANOR STATUS FOR SECOND OFFENSES AND MAKE A SECOND OFFENSE PUNISHABLE AS A FELONY." Id. at 435.

${ }_{60}$ See Note, An Attempt to Regulate Pornography Through Civil Rights Legislation: Is It Constitutional?, 16 U. ToL. L. REv. 231, 306-07 (1984) (arguing that existing ordinances based on this theory are unconstitutional). 
harm to the distribution of sexually explicit material, this response proposes a new regulatory scheme that coordinates prosecutorial and private civil enforcement.

Andrea Dworkin and Catherine MacKinnon outline the radical feminist attack on pornography. From this perspective, pornography "institutionalizes the sexuality of male supremacy, fusing the erotization of dominance and submission with the social construction of male and female." ${ }^{\text {B1 }}$ For its "overwhelmingly" male audiences, ${ }^{62}$ pornography eroticizes violence against women. Pornography's portrayal of women is defined by "its view of what men want sexually, such that acts of rape, battery, sexual harassment, prostitution, and sexual abuse of children become acts of sexual equality."63 MacKinnon insists that this is no harmless fantasy, but rather that pornography provides the stimulus for sexual assault. Pornography does more than mirror people's perceptions- "It moves them." "are lived out, circumscribing the status of half the population."

MacKinnon and Dworkin have proposed a model ordinance that features a broad prohibition of pornography. ${ }^{68}$ Adopting the model with few changes, the Indianapolis City Council defined pornography broadly to incorporate sexually explicit material depicting women in anything less than a role of equality. ${ }^{67}$ MacKinnon argues that the

61 MacKinnon, Pornography, Civil Rights, and Speech, 20 HARv. C.R.-C.L. L. REv. 1, 18 (1985) [hereinafter MacKinnon, Civil Rights]; see also MacKinnon, Not a Moral Issue, 2 YALE L. \& PoL'y Rev. 321, 325 (1984) [hereinafter MacKinnon, Moral Issue] ("Pornography, in the feminist view, is a form of forced sex, a practice of sexual politics, an institution of gender inequality.").

${ }_{62}$ MacKinnon, Civil Rights, supra note 61, at 19; see also Dworkin, Against the Male Flood: Censorship, Pornography and Equality, 8 HARv. Women's L.J. 1, 8 (1985) ("The act that obscenity recognizes is erection, and whatever writing produces erection is seen to be obscene . . . "); MacKinnon, Moral Issue, supra note 61, at 336 ("The theory of the First Amendment under which most pornography is protected from governmental restriction proceeds from liberal assumptions which do not apply to the situation of women." (footnote omitted)).

6s MacKinnon, Civil Rights, supra note 61, at 17.

64 Id. at 55 (emphasis omitted).

6s Id.

${ }^{66}$ See $i d$. at $1 \mathrm{n} .1$ (reproducing in full the model ordinance's definition of pornography).

67 Pornography is defined as:

the graphic sexually explicit subordination of women, whether in pictures or in words, that also includes one or more of the following:

(1) Women are presented as sexual objects who enjoy pain or humiliation; or

(2) Women are presented as sexual objects who experience sexual pleasure in being raped; or

(3) Women are presented as sexual objects tied up or cut up or mutilated or bruised or physically hurt, or as dismembered or truncated or fragmented or severed into body parts; or 
right to consume pornography cannot come at the expense of equality rights. The ordinance, she argues, is not a ban "unless relief for a proven injury is a 'ban' on doing that injury again." ordinance was held unconstitutional by the Seventh Circuit, ${ }^{69}$ the concept drew support from the Meese Commission. Finding itself "in substantial agreement with the motivations behind the [Indianapolis] ordinance," recognizing a civil remedy for harms attributable to pornography. ${ }^{71}$ In cases of an individual coerced into a pornographic production, the forcing of pornography on a person, assault directly caused by specific pornography or trafficking in pornography, the Commission endorsed a civil remedy, subject to procedural safeguards. ${ }^{72}$ The radical feminist theory provides the censor with a new justification.

\section{Censorship and Videotape Distribution}

Citizen groups that have put video stores under intense scrutiny ${ }^{73}$

(4) Women are presented as being penetrated by objects or animals; or

(5) Women are presented in scenarios of degradation, injury, abasement, torture, shown as filthy or inferior, bleeding, bruised, or hurt in a context that makes these conditions sexual; or

(6) Women are presented as sexual objects for domination, conquest, violation, exploitation, possession, or use, or through postures or positions of servility or submission or display.

American Booksellers Ass'n v. Hudnut, 771 F.2d 323, 324 (7th Cir. 1985) (quoting INDIANAPOLIS CODE $\S 16-3 q$ ), affd mem., 475 U.S. 1001 (1986).

${ }^{68}$ MacKinnon, Civil Rights, supra note 61, at 25; see also MacKinnon, Moral Issue, supra note 61, at 332 ("Besides, if a woman is subjected, why should it matter that the work has other value?").

${ }^{89}$ See American Booksellers Ass'n, 771 F.2d 323 (7th Cir. 1985); see also infra notes 224-30 and accompanying text.

701 FinAL REPORT, supra note 4, at 393.

71 See id. at 457 (Recommendation 87: "LEGISLATURES SHOULD CONDUCT HEARINGS AND CONSIDER LEGISLATION RECOGNIZING A CIVIL REMEDY FOR HARMS ATTRIBUTABLE TO PORNOGRAPHY.").

If a procedure could be devised that provided for some preliminary determination by a judge or magistrate that the suit was plausible before the complaint was allowed to be filed, our fears would evaporate, and with such a procedure we believe that civil remedies available to a wide range of people ought seriously to be contemplated.

Id. at 395 (emphasis omitted).

${ }^{73}$ The Kansas City chapter of the Coalition Against Pornography is representative of these groups. The chapter recently devoted $\$ 200,000$ to a media campaign warning of pornography's dangers. See Beachhead in a War on Pornography, N.Y. Times, Nov. 2, 1987, at A16, col. 4, A16, col. 5. Pressuring prosecutors for more stringent enforcement of obscenity laws, the organization has compiled a list of 200 Kansas City outlets where illegal obscene materials are allegedly available. The list includes general purpose video stores. See id. 
are part of the "disturbing rebirth of censorship in the United States."74 This pressure follows the VGR's evolution as the medium of choice for the pornography market. ${ }^{75}$ As X-rated videos increase in popularity, the suburban video store will feature everything from Disney animations to X-rated features. Opponents allege that explicit materials are "creeping into the mainstream."78 Part of the response has been to limit minors' access to violent cassettes. ${ }^{77}$ However, more concerted efforts have been made to regulate distributors handling explicit videotapes. Part of this regulation takes the form of obscenity

74 Cable-Porn and Dial-a-Porn Control Act: Hearings on S. 1090 Before the Subcomm. on Criminal Law of the Senate Comm. on the Judiciary, 99th Cong., 1st Sess. 97 (1985) [hereinafter Cable-Porn Hearings] (testimony of Barry Lynn, ACLU Legislative Counsel).

Media watch groups are prodding prosecutors to action. The FCG's first radio obscenity investigation in nine years coincided with pressure exerted by media watch groups for more assertive regulation. See Davis, supra note 37, at 44, col. 1 . The investigation resulted in a warning to Philadelphia radio station WYSP-FM for "indecent" speech in Howard Stern's morning talk show. A campaign by media watch groups prompted 35 complaints from Stern's Philadelphia audience, estimated at 500,000. See Stengel, Radio Daze, TIME, Apr. 27, 1987, at 32, 32. No warning was issued against the New York station that carries the same program, WXRK-FM. See Stuart, F.C.C. Acts to Restrict Indecent Programming, N.Y. Times, April 17, 1987, at A1, col. 3, C30, col. 4. Similar pressures prompted an estimated 17,000 stores nationwide to drop nonobscene magazines-including Playboy and Penthouse-from their inventories. See Kristoff, X-Rated Industry in a Slump, N.Y. Times, Oct. 5, 1986, § 3, at 1, col. 2, 6, col. 4. After being warned by the Meese Commission that they might be named in the final report, 4500 "7-Eleven" convenience stores removed the sex-oriented magazines. See id.

76 Industry executives estimate that three-quarters of the nation's video stores carry adult titles. The Video Software Dealers Association indicates that this material accounts for about $13 \%$ of their business, valued at $\$ 250$ million annually. See Cieply, Risque Business: Video Outlets Face Mounting Pressure to Stop Carrying X-Rated Cassettes, Wall St. J., April 21, 1986, at 20D, col. 1, 20D, col. 1; see also infra notes $158-60,231-236$ and accompanying text.

${ }^{78}$ Lindsey, supra note 42, at B14, col. 3 (quoting Jane Miller, Minneapolis' Pornography Research Center).

77 See, e.g., Child's Play, TIme, June 1, 1987, at 31, 31 (The increased availability of cassettes depicting graphic violence has prompted legislative demands for ratings and age restrictions comparable to those in motion picture cinemas.); Nordheimer, supra note 2 (Local organizations and state legislators seek to prevent minors from buying or renting violent tapes by imposing ratings and age restrictions.).

These efforts reflect broader concerns over the availability of pornography to minors through new technologies. See Brian T. v. Pacific Bell, No. CH 128655-7, at 1-2 (Cal. Super. Ct. filed Oct. 28, 1987) (complaint on file with the University of Pennsylvania Law Review) (plaintiffs allege that a twelve-year-old boy's access to telephone "dial-a-porn" services incited him to sexually assault a four-year-old girl); Declaration of Dr. Victor B. Cline in Support of Preliminary Injunction at 4-5, Brian T. v. Pacific Bell, No. CH 128655-7, at 1-2 (Cal. Super. Ct. filed Nov. 13, 1987) (on file with the University of Pennsylvania Law Review) (clinical psychologist submitting expert opinion that exposure of children to pornographic materials sometimes "serves as the basis for various psychological complications"). 
prosecutions aimed at videotape distributors. ${ }^{78}$ Stepped-up federal prosecution ${ }^{79}$ is evident in the use of racketeering indictments against video store proprietors. ${ }^{80}$ Local authorities resort to more subtle pressure. ${ }^{81}$ These less sophisticated enforcement measures can reach conventional Hollywood fare well outside the boundaries of obscenity law. ${ }^{\mathbf{2 2}}$ The Miller doctrine creates an incentive to bring legal action as a means of shaping community standards. ${ }^{83}$ The prosecutions have been effective: both local and national video distributors have responded by withdrawing from the adult market. ${ }^{84}$ This contraction of first amendment rights occurs without a judicial articulation of the constitutional rights to be afforded this medium. As yet, the courts have failed to assess the VCR

78 Videotape distributors and video-shop owners have faced obscenity prosecutions in Ohio, Alabama, Arizona, and Florida. See Cieply, supra note 75, at 20D, col. 1. "There is definitely a concerted effort on the part of some civic groups, community people and even the federal government to suppress what's on the video-store shelves'. . . Id. at 20D, col. 2 (quoting John Pough, President, Video Software Dealers Association).

${ }_{79}$ Federal adult obscenity indictments increased from 10 in 1986 to 71 in 1987. See Shenon, Justice Dept. Plans Anti-Racketeering Drive Against Pornographies, N.Y. Times, Jan. 12, 1988, at A16, col. 1, A16, col. 1. William F. Weld, head of the Justice Department's Criminal Division, has predicted that "[1988] will be a big year for obscenity prosecutions." Id.

${ }_{80}$ See United States v. Pryba, Crim. No. 87-00208-A (E.D. Va. Nov. 3, 1987) (upholding constitutionality of indictments against video store owners for violations of Racketeer Influenced and Corrupt Organizations Act ("RICO"), 18 U.S.C. §§ 196168 (1982 \& Supp. IV 1986)). Although only a handful of items were found obscene, the defendants in Pryba were ordered to hand over assets valued at $\$ 1$ million. See Shenon, supra note 79, at A16, col. 2. ACLU Legislative Counsel Barry Lynn states that such prosecution "poses as substantial a threat to the rights of booksellers and video stores as any single initiative by the Federal Government." Id. at A16, col. 1.

${ }_{81}$ This pressure often consists of an informal visit from local police officers who warn of impending criminal proceedings if "obscene" videotapes are not removed. See, e.g., Vernon Beigay, Inc. v. Traxler, 790 F.2d 1088, 1090-91 (4th Cir. 1986) (finding no evidence for plaintiff"s claim of "chilled" first amendment rights under 42 U.S.C. $\S 1983$ (1982) because he failed to show that the threatening officers acted under color of state law). The coercive-and imprecise-potential of such regulation is obvious.

${ }^{82}$ After viewing "The Girls of Penthouse," the Stamps, Arkansas City Council determined that the tape was obscene. The Council ordered a local video store to remove "offensive materials" within 30 days. A list of films included "for reference" included the youth comedy "Young Doctors in Love," which has appeared on ABC television. See Horn, "A Very Clean City" vs. R-Rated Videocassettes, L.A. Times, Apr. 16, 1985, $\S \mathrm{VI}$, at 1 , col. 1, 1, cols. 3-4. A federal court found the enforcement measures unconstitutionally vague and overbroad. See Marjak, Inc. v. Cowling, 626 F. Supp. 522, 527 (W.D. Ark. 1985).

8s Proponents of obscenity laws claim that failure to bring actions against videotape distributors "in the good part of town" usurps more conventional obscenity actions. Defendants argue successfully that their cases create an unfair double standard when the community tolerates comparable material in "mainstream" video stores. See Cieply, supra note 75 , at $20 \mathrm{D}$, col. 3 .

84 Both the nation's largest video wholesale distributor and franchise chain have dropped adult material. Many video store owners in North Carolina and Phoenix, Arizona dropped X-rated cassettes in the wake of vigorous prosecutions. See id. 
as an expressive innovation.

\section{Technological Change and Broadcast Speech}

The VCR's appearance on the market coincides with other technological change that undermines the foundations of traditional broadcast regulation. Cable television service ${ }^{85}$ has altered the nature of broadcast regulation. That regulation is premised on a belief that differences inherent in broadcast speech allow for greater intervention than is allowed with the print media. ${ }^{86}$ The fairness doctrine ${ }^{87}$ and the prohibition of nonobscene "indecent" speech $^{88}$ represent content regulation that would be unconstitutional in a nonbroadcast forum. ${ }^{88}$ Cable is one force requiring regulators "to reconsider First Amendment principles that were developed for another market." portant prelude to a consideration of constitutional rights in VCR use. Cable shares with the VCR the use of the television screen. Yet each alters the medium fundamentally. The VGR furthers this change in the market.

${ }^{85}$ Cable distributes video signals to households by coaxial cable. The innovation has meant a myriad of new services for the consumer. See Geller \& Lampert, Cable, Content Regulation and the First Amendment, 32 CATH. U.L. REv. 603, 603 (1983) (programming now available includes cable networks devoted to sports, news, Spanish programming, children's fare, and text services). In 1984, only $18.63 \%$ of total cable subscribers received systems offering twelve channels or less. See Inquiry, supra note 8, at 210 .

${ }^{86}$ See L. Powe, American Broadcasting and the First Amendment 3 (1987) (Because radio "looked different and frivolous," it was subjected to a different

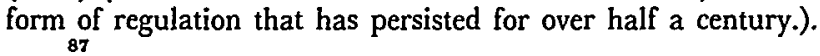

The fairness doctrine, as developed by the Commission, places a two part obligation upon broadcast licensees. First, broadcasters have an affirmative obligation to cover vitally important controversial issues of interest in their communities. Second, they are obligated to provide a reasonable opportunity for the presentation of contrasting viewpoints on those controversial issues of public importance that are covered.

See In re Complaint of Syracuse Peace Council Against Television Station WTVH, 2 F.C.C. Rec. 5043, 5058 n.2 (1987). The requirement initially granted equal access to political candidates. See 47 U.S.C. $\$ 315$ (a) (1982). It was incorporated into the Commission's regulations as the obligation "to afford reasonable opportunity for the discussion of conflicting views on issues of public importance." 47 G.F.R. $\$ 73.1910$ (1985).

${ }_{88}$ See infra notes $115-48$ and accompanying text.

89 See Syracuse Peace Council, 2 F.C.C. Rec. at 5057 ("Under a traditional First Amendment analysis, the type of governmental intrusion inherent in the fairness doctrine would not be tolerated if it were applied to the print media." (citation omitted)); L. POWE, supra note 86, at 200 (Early Supreme Court decisions on the fairness doctrine upheld regulation "that would be inconceivable-and unconstitutional-if applied to the print medium.").

${ }^{80}$ Syracuse Peace Council, 2 F.C.C. Rec. at 5054. 


\section{A. Diminishing Scarcity and the Fairness Doctrine}

Scarcity in the broadcast spectrum is the "cornerstone" of the fairness doctrine. ${ }^{91}$ Free exclusive use of the limited broadcasting spectrum has been accompanied by a lower threshold of first amendment protection. "Unlike other modes of expression, radio inherently is not available to all,"92 the Supreme Court concluded in 1943. "That is its unique characteristic, and that is why, unlike other modes of expression, it is subject to governmental regulation." "93 In exchange for granting a part of this limited spectrum, the fairness doctrine guaranteed fair use of the resource as a public forum. In 1949, the FCC delineated the fairness doctrine to safeguard the public's right to presentation of "different attitudes and viewpoints concerning . . . vital and often controversial issues . . . ."94 The scarcity argument emphasizes that "[i]t is the right of viewers and listeners, not the right of the broadcasters, which is paramount." 95 With the free grant of the public domain comes a public responsibility.

Continuing belief in this scarcity rationale has been the foundation of the fairness doctrine's ongoing validity. This scarcity was prominent in the Supreme Court's affirmance of the doctrine in Red Lion Broadcasting Co. v. Federal Communications Commission. ${ }^{96}$ When potential broadcasters outnumber available frequencies, "it is idle to posit an unabridgeable First Amendment right to broadcast comparable to the right of every individual to speak, write or publish."97 The government could require the licensee "to conduct himself as a proxy or fiduciary

91 See Fowler \& Brenner, A Marketplace Approach to Broadcast Regulation, 60 TEx. L. Rev. 207, 221 (1982).

${ }_{92}$ National Broadcasting Co. v. United States, 319 U.S. 190, 226 (1943).

9s Id.

94 In re Editorializing by Broadcast Licensees, 13 F.C.C. 1246, 1249 (1949).

${ }^{95}$ Red Lion Broadcasting Co. v. FGC, 395 U.S. 367, 390 (1969). Even with an increase in broadcasting facilities, labor unions and maverick politicians assert that the doctrine remains necessary for those with unpopular speech. See To Provide That the Federal Communications Commission Shall Not Regulate the Content of Certain Communications: Hearings on S. 1917 Before the Senate Comm. on Commerce, Science, and Transportation, 98th Cong., 2d Sess. 199 (1984) [hereinafter Packwood Hearings] (testimony of Laurence Gold, AFL-CIO Special Counsel) ("Over the years trade unions have found that the fairness doctrine, though feeble, is the best hope of assuring that commercial television and radio stations air labor's side of controversial issues of the day, most particularly collective bargaining disputes and other matters concerning workers' rights."); see id. at 191 (testimony of Susan Kokinda, Lyndon Larouche Campaign Washington representative) ("The control exerted by the Manhattan-based major networks can and does lead to the actual suppression of important political and social viewpoints which are not approved of by the network hierarchy, and the East Coast financial interests they represent.").

98 395 U.S. 367 (1969).

${ }^{87} \mathrm{Id}$. at 388 . 
with obligations to present those views and voices which are representative of his community . . . "98 The fairness doctrine obligation remains distinctive to the broadcast medium. The Supreme Court has refused to extend the doctrine to the print media, ${ }^{89}$ political advertising, ${ }^{100}$ or public utilities. ${ }^{101}$ In 1974 , the FCC reaffirmed the fairness doctrine, concluding that "the problem of scarcity is still very much with us . . ."102 Into the 1980 s, the Court has held that the broadcast licensee is "granted the free and exclusive use of a limited and valuable part of the public domain . . ."103 In 1984, the Court ruled that, barring "some signal" from the FCC to "reconsider our longstanding approach," Congress retains the power to regulate the use of this scarce and valuable national resource. ${ }^{104}$ Consequently, the scarcity rationale remains central to content regulation of broadcast speech. ${ }^{105}$

Cable's destruction of the scarcity rationale was pivotal in the FGC's August 1987 conclusion that the fairness doctrine "is unconstitutional on its face."106 Enhanced by technological advances, cable spurred an explosion in the number of broadcast stations, increasing significantly the amount of information available. ${ }^{107}$ These develop-

88 Id. at 389.

${ }^{89}$ See Miami Herald Publishing Co. v. Tornillo, 418 U.S. 241, 258 (1974).

100 See Columbia Broadcasting Sys. v. Democratic Nat'l Comm., 412 U.S. 94, 123-24 (1973).

101 See Pacific Gas \& Elec. Co. v. Public Util. Comm'n, 475 U.S. 1, $20-21$ (1986) (invalidating regulation requiring a utility that disseminated political editorials to publish opponents' views as well).

${ }_{102}$ In $r e$ The Handling of Pub. Issues Under the Fairness Doctrine and the Pub. Interest Standards of the Communications Act, 48 F.C.C.2d 1, 6 (1974). "The effective development of an electronic medium with an abundance of channels through the use of cable, or otherwise is still very much a thing of the future." Id.

${ }_{103}$ Columbia Broadcasting Sys. v. FCC, 453 U.S. 367, 395 (1981) (quoting Office of Communication of the United Church of Christ v. FCG, 359 F.2d 994, 1003 (D.C. Cir. 1966)).

104 See FCC v. League of Women Voters, 468 U.S. 364, 376 n.11 (1984).

108 See, e.g., L. PowE, supra note 86, at 208 ("Outside the legal literature, the belief in scarcity exists-or at least the assertion of scarcity exists-because those who wish to continue broadcast regulation believe that it must exist; otherwise, broadcasters could not be controlled by the government.").

${ }^{108}$ In re Complaint of Syracuse Peace Council Against Television Station WTVH, 2 F.C.C. Rec. 5043, 5047 (1987).

107 The FCC endorsed its 1985 finding that "the interest of the public in viewpoint diversity is fully served by the multiplicity of voices in the marketplace today." Syracuse Peace Council, 2 F.C.C. Rec. at 5051 (citing Inquiry, supra note 8, at 147). From 1950 to 1983, the number of television and radio stations increased $1100 \%$ and $300 \%$ respectively. See Notice of Inquiry, 49 Fed. Reg. 20,317, 20,323 (1984). Nationwide, there are 1315 television stations and 10,128 radio stations; $96 \%$ of the public has access to five or more television stations. See Syracuse Peace Council, 2 F.C.C. Rec. at 5051. This growth and the development of "new electronic information technologies," the FCC concluded in 1985, "provides the public with suitable access so as to render the fairness doctrine unnecessary." Inquiry, supra note 8, at 197. 
ments belie Justice Frankfurter's determination that the "spectrum simply is not large enough to accommodate everybody."108 Today, there is "no inherent shortage of spectrum capacity from the technological point of view." 109 A broadcaster's financial considerations, rather than the availability of channels, determine entry into the market. ${ }^{110}$ Noting that the scarcity rationale, in itself, was always a tenuous basis for regulation, ${ }^{111}$ the Commission also pointed to the doctrine's chilling effect ${ }^{112}$ and overbreadth as reasons for its destruction. ${ }^{113}$ Cable television

108 National Broadcasting Co. v. United States, 319 U.S. 190, 213 (1943).

109 Packwood Hearings, supra note 95, at 31 (testimony of Dr. Robert S. Powers, FCC Chief Scientist) ("WW]e have stretched the high frequency limits of spectrum use, and ... we have continually made better use of the spectrum we have available."). This expansion translates into greater broadcast availability. In 1985, the FCC had more than 500 vacant television channels available nationwide. See Inquiry, supra note 8, at 207. In 1987, the FCG had 1266 radio allotments available for licensing. See Syracuse Peace Council, 2 F.C.C. Rec. at 5053 n.177.

Compared to broadcast media, newspapers are scarce, and the print medium is contracting. In contrast to more than 11,000 broadcast stations, there are 1657 daily newspapers in the United States and only 125 cities have two or more dailies. See id. at 5051. Only three major metropolitan newspapers have appeared on the market since World War II-Long Island's Newsday, The Washington Times, and USA Today, see Packwood Hearings, supra note 95, at 35-36 (statement of Sen. Packwood, questioning Dr. Powers), while Baltimore, Washington, Philadelphia, Cleveland, Buffalo, and Hartford have seen newspapers die recently. See L. PowE, supra note 86, at 205. "Wholly unexpectedly, we have reached the situation where a daily newspaper comes quite close to being a natural monopoly." Id. at 206.

110 See Fowler \& Brenner, supra note 91, at 223; see also Packwood Hearings, supra note 95, at 31 (testimony of Dr. Powers) ("[O]ne can always squeeze in a little bit more service if you decide you want to and make the effort, spend the money that it costs to do so.").

${ }^{111}$ In Telecommunications Research and Action Center v. FCC, 801 F.2d 501 (D.C. Cir. 1986), cert. denied, 107 S. Ct. 3196 (1987), the court noted that: the line drawn between the print media and the broadcast media, resting as it does on the physical scarcity of the latter, is a distinction without a difference. ...

All economic goods are scarce. . . . Since scarcity is a universal fact, it can hardly explain regulation in one context and not another. The attempt to use a universal fact as a distinguishing principle leads to analytical confusion.

Id. at 508 (footnote omitted).

Moreover, the FCC notes that government allocation of scarce newsprint during World War II did not lead to content-based regulation of the news media. The rationing forced some newspapers to curtail size, reduce editions, or even go out of business. Although government allocation reduced available newspaper speech it "did not give rise to the imposition of obligations on the remaining newspapers to make their facilities available for those speakers who were silenced." Syracuse Peace Council, 2 F.C.C. Rec. at 5055 n.202.

112 See Syracuse Peace Council, 2 F.G.G. Rec. at 5049. The fairness doctrine creates an incentive to direct programming toward "orthodox and well-established opinion on controversial issues"; the threat of expensive litigation inhibits robust debate on timely issues. Id. The Commission's 1985 study of the efficacy of the fairness doctrine documented 60 reported instances of such inhibition of controversial coverage. See id. at 5050 . 
set the stage for the FCC's first recognition that "full First Amendment protections against content regulation should apply equally to the electronic and the printed press." 114

\section{B. Cable Television and Indecent Speech: The Tolerant Forum}

Cable television's avoidance of indecent content regulation is a second development important to VCR technology. Important parallels underlie this development: cable, like the VGR, broadened the viewer's choice and was met with efforts to restrict that choice. The Meese Commission concluded that cable's fare "is often substantially more sexually explicit than anything that would be available on broadcast television." ${ }^{\text {"11s }}$ Not all of this selection is welcomed. Media watch groups seek to reverse this "erosion on TV" that places the nation at a "moral Dunkirk."116 Proposed legislative bans set proscriptions that reach speech that is not obscene but could be termed "indecent."117

113 See id. at 5052.

114 Id. at 5057; see also Loveday v. FCG, 707 F.2d 1443, 1459 (D.C. Cir.) (When the number of broadcast stations "rivals . . . the number of newspapers and magazines in which political messages may effectively be carried . . . the [first amendment] protections accorded printed messages are not wholly irrelevant to broadcast freedoms."), cert. denied, 464 U.S. 1008 (1983).

${ }_{116} 1$ Final REPORT, supra note 4, at 282. Examples of such material include talk shows with sexual advice, music videos with sexual or violent themes, channels devoted to sexual fare and uncut mainstream motion pictures. This material typically is not obscene; it involves "a degree of sexuality somewhat closer to what is available in a mainstream motion picture theater" than what is on television. Id. at 283. The cable operator must do more than gear programs to the mass audience; there is an economic interest in providing subscribers with many alternatives. See Krattenmaker \& Esterow, Censoring Indecent Cable Programs: The New Morality Meets the New Media, 51 FordhaM L. REv. 606, 607 (1983). Since the service supplements material available from broadcast channels for a surcharge, it must, by definition, be different. See, e.g., Comment, Content Regulation of Cable Television: "Indecency" Statutes and the First Amendment, 11 RuTGERs CoMPUTER \& TECH. L.J. 141, 153 (1985) (noting that cable subscribers pay an additional fee to obtain specialty channels).

${ }_{116}$ Cable-Porn Hearings, supra note 74 , at 53 (testimony of Jack D. Clancy, former prosecutor). Columnist Jack Anderson wrote congressmen claiming that "lascivious [cable] programs" involving "lurid sex scenes, sex acts and other obscenities" constitute the sexual education of many American children. Id. at 6.

${ }_{117}$ Senator Jesse Helms sponsored legislation that would forbid the distribution of "obscene, indecent or profane matter, by means of radio or television, including cable television." Cable-Porn and Dial-a-Porn Control Act, S. 1090, 99th Cong., 1st Sess. § 2(a), 131 CoNG. REC. S5544-45 (daily ed. May 7, 1985). Similarly, a media watch group, Morality in Media, provides the following model statute that would prohibit the distribution of "indecent material": "Indecent Material' shall mean material which is a representation or a verbal description of:

1. a human sexual or excretory organ or function; or

2. nudity; or

3. ultimate sexual acts, normal or perverted, actual or simulated; or

4. masturbation; 
These efforts rely heavily on Federal Communications Commission v. Pacifica Foundation. ${ }^{118}$ The Pacifica plurality upheld the statutory prohibition against "obscene, indecent, or profane" speech" ${ }^{119}$ on two theoretical grounds. First, the pervasive influence of the broadcast media means that offensive, indecent material "confronts the citizen, not only in public, but also in privacy of the home, where the individual's right to be left alone plainly outweighs the First Amendment rights of an intruder." 120 Second, the Court reiterated Ginsberg's protection of the state interest in the well-being of children. Pacifica's broadcast could have "enlarged a child's vocabulary in an instant."121 These factors outweighed the limited first amendment rights afforded to broadcast speech. ${ }^{122}$ Proponents of cable regulation argue that regulation of cable services can be clothed in the Pacifica standard.

The argument favoring such regulation views cable and broadcast television similarly. Early in cable television's development, the Supreme Court recognized the FCG's authority to regulate cable as "reasonably ancillary" to its regulation of television. ${ }^{123}$ First, cable shares broadcasting's pervasiveness; a quarter of a million subscribers are added each month. ${ }^{124}$ Such widespread use does not make the medium less intrusive. Second, this pervasiveness means children can watch $\mathrm{R}$ rated movies they could not see otherwise without an accompanying

which under contemporary community standards for cable television is patently offensive." Morality in Media Model Indecency Statute $\S 1(\mathrm{e})$, reproduced in Krattenmaker \& Esterow, supra note 115, at 610-11 n.19.

118438 U.S. 726 (1978). The current debate started with New York radio station WBAI-FM's afternoon broadcast of George Garlin's "Filthy Words" routine in October, 1973. The FCC deemed the monologue "indecent" and placed a declaratory order in the station's license file to be considered if other complaints were received. In re Gitizen's Complaint Against Pacifica Foundation Station WBAI (FM), 56 F.C.C.2d 94, 99 (1975). Indecent language, the FCC ruled, "describes in terms patently offensive as measured by contemporary community standards for the broadcast medium, sexual or excretory activities and organs, at times of the day when there is a reasonable risk that children may be in the audience." Id. at 98.

119 Federal Communications Comm'n Act, ch. 652, § 326, 48 Stat. 1091 (codified as amended at 18 U.S.C. $\S 1464(1982)$ ).

120 Pacifica, 438 U.S. at 748.

${ }^{121}$ Id. at 749 (citing Ginsberg v. New York, 390 U.S. 629 (1968)).

122 Id. at 750 .

${ }^{123}$ United States v. Southwestern Cable Co., 392 U.S. 157, 178 (1968).

124 See 1 FinAL REPORT, supra note 4, at 579; see also Riggs, Indecency on the Cable: Can It Be Regulated?, 26 ARIz. L. REv. 269, 314-15 (1984) ("[I]nstallations are increasing rapidly, and the numbers are large enough that cable's relatively smaller share of the market should not be a fact of constitutional significance."); Comment, supra note 115, at 163 (" $\mathrm{A}] \mathrm{s}$ the number of homes wired for cable increases and begins to approach the number of homes containing television sets, the privacy considerations voiced by proponents of content restraints become difficult to distinguish from a broadcasting analysis." (footnote omitted)). 
adult. ${ }^{125}$ Third, some courts extend the notion of the scarcity of broadcast frequencies to cable. The Tenth Circuit has noted that the laying of cable wire involves "disruptive use of the public domain."128 The limit in the number of cables that can be strung and the monopolistic nature of the industry "make the cable broadcasting medium 'scarce' in much the same way as the finiteness of the electromagnetic spectrum makes wireless broadcasting a medium of essentially limited access."127 Finally, the television and print media are different; "[n]ewspapers and cable television cannot be equated."128 While "[a]ny person may distribute a written message in the form of a leaflet, pamphlet, or other relatively inexpensive form of 'publication," "128 few have the millions needed to establish a cable company. When cable is seen as an extension of television, its visual impact makes the Pacifica concerns more compelling. ${ }^{130}$

This argument has not prevailed because of two weaknesses in the Pacifica precedent. First, the Supreme Court plurality opinion emphasized that the ruling is highly fact-specific. ${ }^{131}$ Second, other critics point to the incongruity of labeling a radio broadcast as intrusive, thus creating an artificial basis on which to differentiate broadcasting from other forms of communication. ${ }^{132}$

The fact-specific basis of the Pacifica holding is seen in the importance of the midday timing of the monologue's broadcast to the outcome; a late-evening presentation, when fewer children are awake, could have produced a different outcome. ${ }^{133}$ Seen in this light, Pacifica

${ }^{125}$ See 1 Final REPORT, supra note 4, at 574. The Commission notes that the Pacifica court was not swayed by arguments that technology could limit children's access to obscene materials. See id. at 581.

${ }^{128}$ Community Communications Co. v. City of Boulder, 660 F.2d 1370, 1378

(10th Cir. 1981), cert. dismissed, 456 U.S. 1001 (1982).

127 Id.

${ }^{128}$ Berkshire Cablevision of Rhode Island, Inc. v. Burke, 571 F. Supp. 976, 985 (D.R.I. 1983), vacated as moot, 773 F.2d 382 (1st Cir. 1985).

128 Id. at 986.

130 See Krattenmaker \& Esterow, supra note 115, at 624; see also Riggs, supra note 124, at 316-17 ("In a very real sense, the 'basic service' of cable television, which by FCC regulation is still required to carry the signals of local television broadcasters, is simply 'more of the same.' The variety may be greater . . . but greater variety probably increases the prospect that something offensively indecent will be transmitted.").

131 Pacifica, 438 U.S. at 750 ("It is appropriate. . . to emphasize the narrowness of our holding.").

132 See L. Powe, supra note 86, at 210 ("Americans bring radios and television sets into their homes because they desire them. . . . [T]here is no law requiring that a radio or television be turned on. Yet this is just what the [Pacifica] Court seems to be hinting.").

${ }^{133}$ Compare In re Pacifica Found. Station, 56 F.C.C.2d 94, 100 (1975) (indicating late evening broadcast of the offensive words may have been permitted if a warning were given and the program had serious literary, artistic, political, or scientific value) 
is a "case about seven dirty words on radio and no more." did not purport to regulate speech in a broader sense. The Court took pains to distinguish Cohen v. California, ${ }^{135}$ a 1971 determination that the "verbal cacophony" protected by the first amendment includes offensive, nonobscene speech. ${ }^{136}$ The majority conceded that some of the words in the monologue had been protected in other contexts. ${ }^{137}$ This internal inconsistency undermines Pacifica's persuasiveness. Even the Meese Commission could not agree on an endorsement of an indecency ban for cable television. ${ }^{138}$ Professor Lawrence Tribe joins other commentators in limiting Pacifica to its facts, to be eventually "discarded as a 'derelict in the stream of the law'."139

Pacifica's weakness as a basis for distinguishing different types of media is implicit in an emerging judicial consensus that indecent cable programming, short of obscenity, cannot be proscribed by regulators. ${ }^{140}$ Federal courts have recently invalidated state $^{\mathbf{1 4 1}}$ and municipal ${ }^{\mathbf{1 4 2}}$ indecency statutes. While cable arguably is pervasive, it is not intrusive in the sense the Court suggested in Pacifica. Cable regulation amounts to the supervision of private "contractual choices."143 Cable signals "do not travel except upon request. . . . They are invited."144 This conscious and continuing choice to purchase the programming makes it impossible to characterize cable television as an intruder. Moreover, parents can control children's access to indecent material on cable-a central concern of the Pacifica ruling. Program classifications and

with Pacifica, 438 U.S. at 750 (discussing the time of day of the broadcast as one of the fact-specific elements of the decision).

134 Krattenmaker \& Esterow, supra note 115, at 627.

135403 U.S. 15, 26 (1971) (holding that absent a compelling reason, the state cannot make the simple public display of a four-letter expletive a criminal offense).

${ }^{136} I d$. at 25.

137 See Pacifica, 438 U.S. at 756 (Powell, J, concurring).

1 se See 1 Final REPORT, supra note 4, at 398-99.

139 L. Tribe, American Constitutional Law 67-68 (1979 Supp.) (quoting North Dakota State Bd. of Pharmacy v. Snyder's Drug Stores, Inc., 414 U.S. 156, 167 (1973)); see also Cox, The Supreme Court, 1979 Term-Foreword: Freedom of Expression in the Burger Court, 94 HARv. L. REv. 1, 45 (1980) (predicting that Pacifica "may come to be viewed as a narrow, highly particular decision pushing a number of doctrinal exceptions to first amendment principles to their limits").

140 See Comment, Indecency on Cable Television-A Barren Battleground for Regulation of Programming Content, 15 ST. MARY's L.J. 417, 438-39 (1984).

${ }_{141}$ See Community Television of Utah v. Wilkinson, 611 F. Supp. 1099, 1108 (C.D. Utah 1985), affd sub nom. Jones v. Wilkinson, 800 F.2d 989 (10th Cir. 1986), aff'd, 107 S. C.t. 1559 (1987).

${ }_{142}$ See Cruz v. Ferre, 755 F.2d 1415, 1422 (11th Cir. 1985); Community Television of Utah, Inc. v. Roy City, 555 F. Supp. 1164, 1172 (N.D. Utah 1982).

143 Community Television of Utah, 555 F. Supp. at 1168.

141 Id. at 1169. 
"lockboxes,"145 the Eleventh Circuit indicated, allow parents to limit the availability of "objectionable" material. ${ }^{148}$ These rulings emphasized the distinctiveness of the cable medium. ${ }^{147}$ Under this view, "Pacifica, which deals with broadcasting, the transmission of electromagnetic waves through the publicly controlled airways, is not applicable. . . . It is irrelevant." 148

\section{Cable's Impact on Broadcast Speech}

Cable has reshaped the judicial view of broadcast expression by establishing the context into which the VCR has been introduced. Traditionally, courts have operated from the premise that "it is broadcasting that has received the most limited First Amendment protection."149 Although cable television employs the television screen-as does the VCR-cable has transformed the process of receiving broadcast information into a process more similar to the print media. ${ }^{150}$ Cable broadens choice beyond the limited broadcast spectrum and enhances viewer control. The VCR has further blurred the lines between the various media and has helped erode the constitutional distinctiveness of broadcast speech. The FGC recognized this development for the first time in the 1987 Syracuse Peace Council case, concluding that "full first amendment protections against content regulation should apply equally to the electronic and printed press."181

146 See Comment, supra note 115, at 144 n.14:

There are several forms of lockout devices. The simplest is a small metal box with a key that, when attached to the cable wire feeding into the television, can block out a specific channel. Another device involves a computer chip that enables the subscriber to punch in a code specifying the channel and the amount of time for which it is to be blocked out.

$I d$.

${ }^{146}$ See Cruz, 755 F.2d at 1420.

117 See G. Shapiro, P. Kurland \& J. Mercurio, Cablespeech 45 (1983) (Cable cases distinguishing Pacifica stress "the substantially greater level of choice and viewing control available to cable television subscribers compared to off-the-air television viewers.").

${ }^{148}$ Community Television of Utah, 555 F. Supp. at 1169.

149 Pacifica, 438 U.S. at 748.

${ }^{150}$ Thus, a content ban would limit the dissemination of diverse material, a result contrary to the first amendment. See Krattenmaker \& Esterow, supra note 115, at 633.

${ }_{161}$ In re Complaint of Syracuse Peace Council Against Television Station WTVH, 2 F.C.C. Rec. 5043, 5057 (1987). The Meese Commission concluded that the FCC already effectively equated cable television with the print media in constitutional terms. See 1 FINAL REPORT, supra note 4, at 282-83 (noting that "cable is not subject to the same range of Federal Communications Commission content regulation" as the broadcast media). 


\section{The VGR AND the First AMENDMent}

The rapidity of the VCR's introduction to the entertainment market has not been matched by a corresponding reinterpretation of constitutional doctrine. Because the recorder subsumes many forms of expression, all media are influenced by its presence. The VGR's importance extends beyond entertainment to the commercial and political arenas. Despite this impact, the judiciary has considered only indirectly the first amendment rights in videotape distribution. These cases have addressed the constitutionality of obscenity statutes and search warrants, as well as the extent of privacy rights in VCR use. Although videotapes constitute an important form of speech in the 1980s, the VCR operates in a constitutional vacuum. Unlike cable, broadcast television, or the print media, there is no judicial articulation of what first amendment rights are indigenous to VCR use.

\section{A. The VCR's Impact}

The VGR quickly has become a communications staple. ${ }^{162}$ Its sudden presence in close to half the nation's households ${ }^{\mathbf{1 5 3}}$ alters aspects of every entertainment medium. This realignment is one of the VCR's two primary influences on the entertainment industry. For example, television networks, straining from cable and independent competition, face advertisers nervous that their commercial messages are being "zapped."154 Movie ticket sales remained flat from 1981 to $1984,{ }^{105}$ while

162 The first unit to sell in significant numbers was Sony's Betamax, introduced in the U.S. in late 1975. Most other major electronic producers were in the market by the 1977 holiday season. Sales increased from 50,000 in 1976 to 750,000 in 1979. See R. Cass, Revolution In THE WASTELAND 106-07 (1981). In 1985, VGRs sold at a rate of 20,000 a day. See Lindsey, VCR's Bring Big Change in Use of Leisure, N.Y. Times, Mar. 3, 1985, at A1, col. 2, A1, col. 4. This pace outstrips the color television's sales in its mid-1960s heyday. See Bernstein \& Lorber, supra note 2, at 20.

${ }^{153}$ A Neilson Station Index survey ending July, 1986 found that $39.9 \%$ of television owners have a VCR. See Use of VCR's Growing, Wary Advertisers Hear, N.Y. Times, Oct. 27, 1986, at D10, col. 4, D10, col. 4. Although sales are slowing, the VCR's penetration was projected to reach $50 \%$ by the end of 1987 . See Slow Motion, supra note 2 , at 1 , col. 1 . This volume has reduced the recorder's operating costs. For example, the average cost of an overnight movie rental declined from $\$ 8.00$ in 1980 to $\$ 3.00$ in 1984 . See Lindsey, supra note 152 , at A24, col. 1. This distribution network has expanded considerably. There are an estimated 15,000-20,000 video specialty stores nationwide; video cassette sales and rentals have extended to bookstores, convenience chains, mass merchandisers, and toy retailers. See Bernstein \& Lorber, supra note 2, at 17-18. The total potential outlets from the 1984 entrants in those categories constitutes an additional 20,000 outlets. See id. at 30 .

"154 There is little consensus on the extent of consumer "zapping"-the use of a VCR remote control to skip commercials on recorded TV programs. An A.C. Neilson Company 1984 survey found that $49 \%$ of those watching recorded programs skipped the advertisements. See Ad 'Zapping' Held Threat to TV Market, Wash. Post, July 18, 
the climb in cable subscriptions slowed ${ }^{156}$ and magazine newsstand sales fell. ${ }^{167}$ The VCR has even restructured the presentation of pornography. While catering primarily to standard motion picture fare, the typical video store includes more explicit fare rated from $\mathrm{R}$ to $\mathrm{X}$, and "a range of even more sexually explicit material is available, not dissimilar to what might be shown in an 'adults only' theater."158 As the VCR becomes "the dominant mode of presentation of non-still [pornographic] material,"159 it decimates other pornography markets. ${ }^{160}$ To varying degrees, the VCR's repercussions are felt in every form of entertainment expression.

The VGR has had an even more pronounced impact on the communications industry through its capacity to expand electronic speech to realms previously ignored by broadcasters. This impact is felt in entertainment because of the VCR's great potential for "narrowcasting"-providing programming for smaller, distinctive audiences. Video

1984, at D1, col. 3, D8, col. 6. James Spaeth, General Foods Corporation General Manager of Strategic Planning and Research, expressed concern about the effectiveness of TV ads, given the projected growth in the VCR market. See id. Television executives respond that the VCR, in fact, enhances network audiences. A survey conducted for the three major networks found that two-thirds of viewers watching recorded programs did not skip commercials. See Majority of VCR Viewers Don't Skip Ads, Study Says, Wall St. J., Dec. 6, 1985, at 4, col. 1, 4, col. 1. Furthermore, the VCR provides an opportunity to increase program audiences with viewers who otherwise would miss the production.

${ }^{185}$ See Lindsey, supra note 152 , at 24 , col. 1. Cf. Staying Home, Wall. St. J., May 19, 1986, at 37, col. 3, 37, col. 3 (56\% of survey respondents reported no change in theater attendance after purchasing a VCR; $41 \%$ went less often).

${ }_{150}$ VCRs have slowed the growth of Home Box Office's cable service subscriptions:
19818.5 million
198211.5 million
198313.5 million
198414.5 million
198514.6 million

See Farber, Cable Services Stressing Compatibility with VCR, N.Y. Times, March 31, 1986, at C18, col. 5. This trend is not true for all companies during the same period. Showtime and Group W Cable say that VCRs have helped their business. See Spillman, Showtime Doesn't Fear VCR's, Advertising AgE, Feb. 18, 1985, at 61, 61; Probing VCR-Pay Cable Compatibility, BroadCasting, Feb. 18, 1985, at 69, 69.

${ }_{167}$ VCRs, along with rising cover prices and heightened industry competition, contributed to a $12 \%$ decline in newsstand sales from 1978 to 1984. See Richter, Magazines Concerned as Store Sales Decline, L.A. Times, July 22, 1985, § IV, at 1, col. 4,1 , col. 4 .

IDs 1 FINAL REPORT, supra note 4, at 283.

${ }^{169} I d$. at 287.

160 See Kristoff, supra note 74, at 1, col. 2. Indicia of this trend include the closing of half the nation's adult movie theaters, the chapter 11 reorganization of Playgirl, and Playboy's circulation drop from 4.1 million to 3.4 million contributing to a $\$ 62$ million loss in the 1986 fiscal year. Id. 
cassettes are tailored for children, ${ }^{161}$ home hobbyists, ${ }^{162}$ those with distinctive entertainment interests, ${ }^{163}$ and sexual ${ }^{164}$ or linguistic ${ }^{165}$ minorities. While television provides standard exercise programs, the VGR market-in addition to mass market promotions-has produced workout videos for pregnant women ${ }^{\mathbf{1 6 8}}$ and handicapped persons. ${ }^{\mathbf{1 6 7}}$ The video cassette allows the electronic media to fill niches that are too narrow for national broadcasters.

The VCR also influences commercial speech. Colleges, ${ }^{168}$ fashion designers, ${ }^{168}$ and realtors ${ }^{170}$ target video cassettes to their respective markets. Financial information once mired in balance sheets comes to life in videotapes. The securities industry makes extensive use of video-

161 See Harmetz, Video Alters Economics of Movie Animation, N.Y. Times, May 1,1985 , at C19, col. 1, C19, col. 1.

${ }_{162}$ In 1983, "how-to" videotapes accounted for two percent of a total $\$ 495$ million in sales. That portion increased to five percent of 1985 's $\$ 2.1$ billion sales market. For example, food columnist Craig Glairborne released a video cassette to coincide with his publication of a new cookbook. See A Growing Market for How-to Tapes, N.Y. Times, Aug. 18, 1985, at G15, col. 1, C15, col. 4.

${ }^{163}$ The small group of admirers of Berlin Alexanderplatz, a dramatization of a celebrated Alexander Doeblin novel, now have access to the production via a 15-hour video cassette. See Price, supra note 7 , at 28 , col. 1 .

104 Humanus Home Video, a Los Angeles company, produces non-sexual programming aimed at the homosexual community. "Gays have to rethink their way of life," Humanus head Peter Fritch says. "There's a trend away from promiscuity and toward lasting relationships. So there's room for home videos dealing with aspects of this way of life." Original Non-Sexual Program for Gay Market, L.A. Times, Aug. $16,1985, \S$ VI, at 22 , col. 1, 22, col. 2.

${ }_{108}$ California video companies target the Hispanic audience with original titles and English movies dubbed in Spanish. See Hunt, Companies Go After a Growing Latino Market, L.A. Times, Aug. 9, 1985, \& VI, at 20, col. 1, 20, col. 2.

${ }_{168}$ The American College of Obstetricians and Gynecologists has produced two videotapes - the first mainstream medical group to participate in commercial patient education aimed at the mass consumer market. See Parachini, Pregnancy, Exercise: An Emphasis on Safety, L.A. Times, May 10, 1985, § V, at 1, col. 3, 20, col. 1.

${ }^{167}$ The National Handicapped Sports and Recreation Association (NHSRA) has designed exercise tapes which allow wheelchair-bound persons, amputees, quadriplegics, and victims of cerebral palsy to exercise at their own pace. See Mitric, Exercising Without Constraint, Wash. Post, Mar. 15, 1986, at H9, col. 1, H9, col. 1.

188 An estimated 200 colleges have made promotional videos that last an average of ten minutes and cost $\$ 20,000$ to $\$ 60,000$. See Swartz, Colleges Take to Silver Screen to Lure Top High School Seniors, Wall St. J., May 17, 1985, at 27, col. 1, 27, col. 1. College applicants, in turn, are producing video cassettes to aid them in the admissions process. Admissions committees find the videos most useful for assessing theater or dance skills that are not reflected well in written applications. See Molnar, Introducing the "Advid", N.Y. Times, Jan. 3, 1988, § 12 (Educ. Supp.), at 55, col. 1, 56, col. 4.

${ }^{169}$ Fashion designers spend up to $\$ 100,000$ producing video cassettes in the style of soap operas and music videos. The three to five-minute productions are shown in department stores and boutiques. See Ohlmeyer Adds Unit for Fashion Videos, N.Y. Times, July 10, 1985, at D17, col. 3, D17, col. 3.

${ }_{170}$ See Kennedy, Property Marketing Enters Video Age, N.Y. Times, Nov. 7, 1984 , at B10, col. 3, B10, col. 3. 
tapes $;{ }^{171}$ viewers turn to their VCRs for guidance with tax reform. ${ }^{172}$ The video cassette is evolving into a modern corporate memo.

The VCR is adapted to political speech that is at the core of first amendment protection. In Poland, ${ }^{173}$ the Soviet Union, ${ }^{174}$ Iran, ${ }^{175}$ and El Salvador, ${ }^{176}$ the video cassette is a primary forum for political dissent. Domestically, the videotape has been integrated into the political mainstream. The VCR was "the new vehicle to get into voters' homes" in the 1986 election campaign. ${ }^{177}$ The current presidential campaign already has seen extensive use of videotapes for fund-raising and strate-

${ }^{171}$ Companies use videotapes to explain mutual funds to brokers or to provide security analysts with information on initial public offerings. See Business Bulletin, Wall St. J., Jan. 8, 1987, at 1, col. 5, 1, col. 5.

172 See Sloane, A Hot Seller: Tax Videos, N.Y. Times, Feb. 14, 1987, at 34, col. 1,34 , col. 1 .

${ }_{173}$ There are 300,000 VCRs in private hands in Poland. An active underground market features banned productions and news commentary. An opposition spokesman predicts that "video techniques will be the most important and most" useful weapon in our hands this year, and within a few years, we will work mostly in this area. The possibilities for free expression in video are unlimited in Poland." Polish Opposition Exploits VCR's, Wash. Post, Mar. 12, 1986, at A1, col. 1, A24, col. 1. "Now that the dizzying life of the Solidarity era has ended, Poles are looking inward," and there is an insatiable market for Western videos. Echikson, In Poland, at Home Video Viewings Are New Cultural Force, Christian Sci. Monitor, Aug. 4, 1986, at 9, col. 1, 9, col. 1. The Polish government acknowledges this demand. It allows sale of Western recorders in foreign currency stores and permits the operation of private rental cassette libraries. A Warsaw electronics company is producing a prototype East European VGR. Production is projected to reach 30,000 units in 1988. See id. at 10, col. 2 .

${ }_{174}$ An underground video depicts Raisa Gorbachev, the USSR's General Secretary's wife, as a vain, extravagant woman. The video reportedly portrays her shopping in London and Paris stores. Mikhail Gorbachev's aides are concerned that the video may be part of a campaign to discredit the Soviet leader. See Taubman, Raisa Gorbachev Is the Target of a Clandestine Soviet Video, N.Y. Times, Apr. 2, 1987, at A1, col. 1, A1, col. 1. Growing concern about the spread of Western videos prompted the Russian Republic, the largest of the Soviet Union's 15 states, to enact legislation making the production or distribution of films propagating "the cult of violence and cruelty" a criminal offense subject to a maximum of two years in prison. Soviet Moves Against Videos Spreading "Cult of Violence", N.Y. Times, Sept. 7, 1986, at A10, col. 6, A10, col. 6.

175 Opponents of the Shah of Iran smuggled video tapes of the Ayatollah Khomeini to bond the devout. Today, "counterrevolutionary" tapes are secretly exchanged as relief from the regime's discipline. See Price, supra note 7, at 28, col. 2.

${ }_{176}$ El Salvador's antigovernment force-the Faribundo Marti para Liberacion Nacional (FMLN) - have turned to videotapes to carry their message. The videos are targeted at Latin American audiences and are translated for use in the United States and Europe. They are directed particularly at those associated with the sanctuary movement and religious, human rights, and Central American organizations. See Epstein, Video Guerillas: Salvadoran Rebels Videotape Their Cause, Then Smuggle Cassettes to US, Christian Sci. Monitor, Aug. 6, 1987, at 3, col. 1, 3, col. 1.

177 Lindsey, Testing the Persuasive Powers of VCR's, N.Y. Times, Apr. 6, 1986, at D24, col. 1, D24, col. 1. The Law and Order Campaign sold $2000 \$ 15$ videotapes calling for the defeat of California Chief Justice Rose Elizabeth Bird. See id. at D24, col. 2 . 
gic purposes. ${ }^{178}$ Beyond inexpensive home movies, "VCR's have created an age of video publishing."178 They have become an important source of information in the late twentieth century.

\section{B. Video Cassette Content Regulation}

\section{Municipal Ordinances and State Obscenity Statutes}

Current interpretation of municipal ordinances ${ }^{180}$ and state obscenity statutes ${ }^{\mathbf{1 8 1}}$ underscores the low standard of first amendment protection afforded to this new information source. Unanimity exists in content regulations that amount to a prior restraint. The ordinances in Gayety Theatres, Inc. v. City of Miami ${ }^{\mathbf{1 8 2}}$ and City of Puducah v. Investment Entertainment, Inc. ${ }^{183}$ provided the basis for one-year business license suspensions following obscenity convictions involving video cassettes. The license suspensions amounted to the regulation of all future expression by these establishments. ${ }^{184}$ A municipality could "no more impose such a prior restraint . . . than could it by ordinance restrain a citizen from speaking in public for one year because the citizen once uttered an obscenity in a public place."185 Absent this limitation of future speech, a community can restrict obscene video tapes. For example, the District Court for the Eastern District of Pennsylvania found the regulation of a drugstore renting video cassettes to be constitution-

${ }^{178}$ Presidential hopefuls Paul Simon, Robert Dole, Jack Kemp, Michael Dukakis, Bruce Babbitt, and Pat Robertson had campaign videos prepared a full year before election day. Videos are used at house parties and fundraisers; direct-mail videos to party activists are a more personal supplement to traditional advertising. See Grove, Campaigns Courting Voters via Their VCR's, Wash. Post, Oct. 28, 1987, at A7, col. 1, A7, col. 2. The "attack video" already has become part of the 1988 campaign lexicon. Id. at A7, col. 4. Dukakis aides prepared a video that highlights similarities in speeches by Senator Joseph Biden and British Labor Party leader Neil Kinnock. See id.

179 Stander, supra note 1, at 492.

180 Video outlets are addressed directly in recently drafted obscenity provisions. See, e.g., Dumas v. City of Dallas, 648 F. Supp. 1061, 1079 (N.D. Tex. 1986) (Dallas ordinance provision addresses "Adult Video Stores"); Marjak, Inc. v. Cowling, 626 F. Supp. 522, 553 (W.D. Ark. 1985) (City of Stamps obscenity ordinance includes videotape within the definition of "materials").

${ }_{181}$ Video outlets or video cassettes are addressed specifically in some state statutes. See, e.g., S.C. Code ANN. § 16-15-375(2) (Law. Co-op. Supp. 1987) (defining material as applied to obscenity sections as "pictures, drawings, videorecordings . . . ."); Tenn. Code AnN. § 39-6-1140(b) (Supp. 1987) (regulating display of X-rated video cassettes within a retail store).

182719 F.2d 1550 (11th Cir. 1983) (citing Miami City Code \& 31-37 (1980)).

183791 F.2d 463 (6th Cir.), cert. denied, 107 S. Ct. 316 (1986).

184 See id. at 470 (noting that "Paducah's procedure of revoking business licenses ... prevents the offending business from engaging in future distribution of protected, nonobscene material anywhere within the City of Paducah").

${ }^{180}$ Gayety Theatres, 719 F.2d at 1552. 
ally sound when it "merely penalize[s] past conduct" consistent with the Miller standard; ${ }^{188}$ this outcome punishes the few who abuse rights of speech "after they break the law [rather] than to throttle them and all others beforehand."187 VCR technology is given this basic level of first amendment protection. ${ }^{188}$

Beyond this minimal threshold, local regulation is subjected to limited first amendment review. The Ninth Gircuit declined to attach constitutional significance to the alleged chilling effect generated by one Arizona County Attorney's announcement that the state's obscenity statute ${ }^{189}$ would be enforced vigorously. ${ }^{190}$ The court termed the removal of adult materials from eighty percent of the area's video stores in the wake of the announcement misguided: "Any chilling effect that may have been based on an incorrect understanding of the law is not constitutionally cognizable."191 Such an interpretation requires video store owners to assess the same Miller standard that Supreme Court Justices find incomprehensible. ${ }^{\mathbf{1 0 2}}$ Yet video operators' limited court victories have been with legislation that failed to track Miller exactly. ${ }^{193}$ The Ninth Circuit cautioned that "[t]hose who conduct their

${ }^{186}$ Brown v. Pornography Comm'n, 620 F. Supp. 1199, 1215-16 (E.D. Pa. 1985).

187 Id. at 1216 (quoting Vance v. Universal Amusement Co., 445 U.S. 308, 316 n.13 (1980) (quoting Southeastern Promotions, Ltd. v. Conrad, 420 U.S. 546, 559 (1975))).

${ }_{188}$ The proscription against prior restraints is a fundamental precept of first amendment jurisprudence. See Nebraska Press Ass'n v. Stuart, 427 U.S. 539, 559 (1976) ("[P]rior restraints on speech and publication are the most serious and the least tolerable infringement on First Amendment rights."); Near v. Minnesota, 283 U.S. 697, 713 (1931) (noting that in "determining the extent of the constitutional protection, it has been generally, if not universally, considered that it is the chief purpose of the guaranty [of liberty of the press] to prevent previous restraints upon publication").

${ }^{189}$ ARIz. Rev. STAT. ANN. $§ 13-3502.2$ (West Supp. 1987) ("A person is guilty of a . . . felony who . . . knowingly: . . 2. Publishes, sells, rents, lends, transports or transmits in intrastate commerce, imports, sends or causes to be sent into this state for sale or commercial distribution or commercially distributes or exhibits any obscene item, or offers to do any such things.").

180 See Polykoff v. Collins, 816 F.2d 1326, 1340 (9th Cir. 1987) (involving an appeal of a district court's denial of declaratory and injunctive relief to a challenge to the constitutionality of Arizona's obscenity statute and felony fine provisions).

181 Id.

192 See supra notes 18-34 and accompanying text. The Ninth Circuit's analysis misses the central point. As John Pough, Video Dealers Association President, notes, "Even if you win a court case, you can spend $\$ 50,000$ or $\$ 75,000$ defending yourself. A lot of owners are asking, 'Is adult worth the risk?' "Cieply, supra note 75, at 20D, col. 2.

${ }^{193}$ See Videophile, Inc. v. City of Hattiesburg, 601 F. Supp. 552, 554 (S.D. Miss. 1985) (municipal ordinance that fails to provide full protection of the Miller test is unconstitutional); see also Miranda v. Hicks, 388 F. Supp. 350, 359 (C.D. Cal. 1974) (per curiam) (California's obscenity statute unconstitutional for failing to meet Miller test either on its face or as construed), rev'd on other grounds, Hicks v. Miranda, 422 
affairs close to the boundary of proscribed activity necessarily incur some risks."194 This highly restrictive interpretation is representative of the VGR's limited first amendment protection.

\section{Search Warrants}

In cases involving search warrants that include video cassettes, the courts similarly have declined to extend special protection. Considering the search of a video store, Justice Rehnquist ruled that a warrant application authorizing the seizure of video cassettes "presumptively protected by the First Amendment should be evaluated under the same standard of probable cause used to review warrant applications generally."195 Rejecting a higher standard of review adopted by the New York Court of Appeals, ${ }^{198}$ Justice Rehnquist deemed "the requirement that the magistrate determine probable cause" to be an adequate "means of safeguarding First Amendment interests."197 More recently, the Fourth Gircuit affirmed that the fourth amendment adequately restricts government officials "engaging in a paradigmatic 'fishing expedition'."188 The court found that grand jury subpoenas served on two video distributors-requiring a copy of each video depicting an individual engaged in sexually explicit conduct - cut too broadly into constitutionally protected speech. ${ }^{199}$ While not a prior restraint, the subpoenas exerted such a heavy cost on the video distributors that they amounted to an "unreasonable and oppressive" strategy. ${ }^{200}$ Videotapes are guaranteed at least this low threshold of first amendment rights in the search warrant context.

\section{Privacy Rights and the VCR}

These rights overlap with the narrow right to privacy recognized

U.S. 332 (1975)

194 Polykoff, 816 F.2d at 1340.

${ }_{108}$ New York v. P.J. Video, Inc., 475 U.S. 868, 875 (1986).

196 See id. at 871.

${ }^{192} I d$. at 875 "We have long recognized that the seizure of films or books on the basis of their content implicates First Amendment concerns not raised by other kinds of seizures." Id. at 873.

${ }^{198}$ In re Grand Jury Subpoena: Subpoena Duces Tecum, 829 F.2d 1291, 1302 (4th Cir. 1987).

${ }^{199}$ The court stated that "when the government seeks to subpoena material that is presumptively protected by the first amendment, it should ... at a minimum, . . . identify[] the requested material in a way that allows the recipient of the subpoena to know immediately whether an item is to be produced or not." Id. One distributor estimated that two-thirds of the 3,000 titles he distributed weekly might contain material mentioned in the subpoena. See id. at 1294-95.

200 Id. at 1301. 
in Stanley $v$. Georgia. ${ }^{201}$ Focusing on protection of the individual in the sanctuary of his home, the Court concluded that the first and fourteenth amendments prohibit making mere possession of obscene material a crime. ${ }^{202}$ Stanley has evolved into a schizophrenic rule of privacy. Within the home, Stanley's protection endures. ${ }^{203}$ Beyond that, the Court steadfastly has declined to extend the privacy shield over any activity to acquire obscene material for private use. The Court did not extend the ruling's protection to individual exchanges of obscene material for private use, ${ }^{204}$ importation for private use, ${ }^{205}$ or even the right to merely acquire obscene material. ${ }^{206}$ The 1969 ruling does not limit federal restriction of interstate transportation of obscene materials, even by private means for private use. ${ }^{207}$ In 1986 , Bowers $v$. Hardwick ${ }^{208}$ demonstrated the limited nature of the Stanley Court's protection of privacy. In Bowers, the Court ruled that constitutional guarantees do not protect the right of homosexuals to engage in consensual sodomy, even in the privacy of the home. ${ }^{208}$

Video software cases involving VCR technology further reflect the

201394 U.S. 557 (1969).

${ }^{202}$ See id. at 568 . The court also stated that "[w]hatever may be the justifications for other statutes regulating obscenity, we do not think they reach into the privacy of one's own home. . . . Our whole constitutional heritage rebels at the thought of giving government the power to control men's minds." Id. at 565. The Stanley ruling followed an earlier conclusion that constitutional guarantees create "zones of privacy." See Griswold v. Connecticut, 381 U.S. 479, 484 (1965).

${ }^{203}$ In the home, MacKinnon concluded, the right to possess pornography is "so sanctified" that it is not challenged even in the feminist model ordinance. MacKinnon, Civil Rights, supra note 61, at 42. Similarly, the Meese Commission's recommendations did not purport to overstep Stanley's limits. See 1 FrNal REPORT, supra note 4, at 260 n.39 ("We do not discuss Stanley because nothing we recommend is inconsistent with it, and no one has suggested to us that we should urge that Stanley be overruled.").

${ }^{204}$ See United States v. Reidel, 402 U.S. 351, 356 (1971) (Stanley "does not require that we fashion ... a constitutional right ... to distribute or sell obscene materials.").

205 See United States v. 12 200-Ft. Reels of Super 8mm Film, 413 U.S. 123, 128 (1973) ("Stanley does not permit one to go abroad and bring such [obscene] material into the country for private purposes."); United States v. Thirty-Seven Photographs, 402 U.S. 363, 376 (1971) ("The trial court erred in reading Stanley as immunizing from seizure obscene materials possessed at a port of entry for the purpose of importation for private use.").

${ }^{206}$ See 12 200-Ft. Reels of Super 8mm Film, 413 U.S. at 126 ("Stanley depended, not on any First Amendment right to purchase or possess obscene materials, but on the right to privacy in the home.").

${ }^{207}$ See United States v. Orito, 413 U.S. 139, 141-42 (1973)(There is no "zone of constitutionally protected privacy [that] follows ... [obscene] material when it is moved outside the home area protected by Stanley.").

208106 S. Ct. 2841, 2846 (1986).

209 Distinguishing the situation in Stanley, the majority ruled that the respondent could not link his claim to an explicit constitutional guarantee. See id. at 2846. 
narrowness of the protection afforded by Stanley. In a decision that was later vacated, a panel of the First Circuit invoked the standard in suppressing video cassettes seized from a private residence. ${ }^{210}$ To allow the searching officers too much discretion, the court ruled, risked the seizure of "nonevidentiary, first-amendment-protected materials." Judge Coffin was "aware of no case . . . in which the Supreme Court ha[d] upheld a content-based seizure of books or films from a private home." to render void an ordinance requiring that booths with coin-operated video recorders in adult oriented establishments be visible from a common area on the premises. Even assuming a theater owner could assert a constitutional privacy right of patrons, this right would not encompass "some kind of right to masturbate themselves and others in the seclusion of these booths." ${ }^{213}$ Moreover, the court in United States $v$. Andersson ${ }^{214}$ emphasized that even if the appellant could claim a right to possess child pornography in his home, that right did not include acquiring or providing such material for private use. ${ }^{215}$ The Andersson court went on to suggest that the state's interest in regulating child pornography "may well extend into the private home."216 No court fully discussed to what extent it would confer privacy rights on home VGR use.

\section{Conclusion}

Constitutional protection of videotape distribution can depend largely on the location of the tapes. The inevitably skewed result is the product of the limited protection afforded VCR technology. While the Supreme Court has "long recognized that each medium of expression presents special First Amendment problems," 217 the courts have failed to articulate what standard should apply to VCR use. Courts blindly group videotapes with motion pictures; ${ }^{218}$ they devote no detailed con-

210 United States v. Diamond, No. 86-1380, slip. op. (1st Cir. Jan. 14, 1987).

211 Id. at 7.

212 Id. at 8 . This protection is weak. Rehearing en banc was granted and the panel opinion vacated. Judge Coffin's subsequent opinion for the court en banc did not address the privacy issue directly. United States v. Diamond, 820 F.2d 10 (1st Cir. 1987).

${ }_{213}$ Broadway Books, Inc. v. Roberts, 642 F. Supp. 486, 492 (E.D. Tenn. 1986).

214803 F.2d 903 (7th Gir. 1986), cert. denied, 107 S. Ct. 962 (1987).

215 Id. at 906-07.

${ }^{218} I d$. at 907 n.3 (citing New York v. Ferber, 458 U.S. 747 (1982)).

217 FCC v. Pacifica Found., 438 U.S. 726, 748 (1978).

218 See, e.g., In re Grand Jury Subpoena Served upon Crown Video Unlimited, Inc., 630 F. Supp. 614, 619 (E.D.N.C. 1986) ("The commercial sale or exhibition of films is a form of expression strictly protected by the first amendment. . . . Videotapes 
sideration to the VCR's distinctive operation. Now that the VCR has become a primary source of information, the time is ripe for this consideration.

\section{A PROPOSED STANDARD}

The VGR medium's extensive use dictates that it should be afforded the highest level of first amendment protection. The recorder represents the melding of the print and broadcast media. This status undermines arguments that would support restrictions. First, the censorship of "harmful" ideas violates the first amendment's tradition. Courts have remained true to that tradition by rejecting the radical feminist response. The videotape market vindicates that rejection by identifying an active female market for pornography. Second, the VGR is a private medium. Its primary household use provides a context for heightened constitutional protection. Third, within this context the rationales for broadcast regulation fail. The videotape has become the twentieth-century handbill. It is now integral to all forms of expression. If the first amendment is to continue to protect "speech," it must adapt to this reality.

\section{A. The VCR and Harmful Ideas}

There is considerable doubt whether sexually explicit videotapes-the target of censorship efforts-contain "harmful" ideas. The alleged link between pornography and sexual assault is the core of the radical feminist argument. This link is highly tenuous. Unlike the Meese Commission, recent national commissions in Canada and the United Kingdom found no direct link between obscenity and rape or exhibitionism. ${ }^{219}$ The Meese Commission itself was uncomfortable with

obviously fall within this category of protected speech, and the stores therefore enjoy a constitutionally protected right to sell videotapes."); Videophile, Inc. v. City of Hattiesburg, 601 F. Supp. 552, 554 (S.D. Miss. 1985) ("Motion pictures and video tapes are clearly entitled to the protection of Miller . ..." (citation omitted)).

${ }_{219}$ American Booksellers Ass'n v. Hudnut, 771 F.2d 323, 329 n.2 (7th Cir. 1985), affd mem., 475 U.S. 1001 (1986). As an important pornography case illustrates, even the most innocuous material can lead to crime:

Heinrich Pommerenke, who was a rapist, abuser, and mass slayer of women in Germany, was prompted to his series of ghastly deeds by Cecil B. DeMille's The Ten Commandments. During the scene of the Jewish women dancing about the Golden Calf, all the doubts of his life came clear: Women were the source of the world's trouble and it was his mission to both punish them for this and to execute them. Leaving the theater, he slew his first victim in a park nearby.

A Book Named "John Cleland's Memoirs of a Woman of Pleasure" v. Attorney Gen., 383 U.S. 413, 432 n.11 (1966) (Douglas, J., concurring in the judgment) (quoting 
the evidence upon which it based its conclusions. ${ }^{220}$ Commission Chairman Henry Hudson conceded that the reluctance of some Commissioners to endorse more stringent measures "undoubtedly" stemmed from "the scarcity of definitive research on [pornography's] negative effects."221 The final report admitted that social science research remains "unsystematic and unfocused. There is still a great deal to be done."222 Assuming the first amendment allowed "harmful" speech to be restricted routinely, social science research on pornography provides weak support for such restriction. ${ }^{223}$ Judicial rejection of the radical feminist position complies with first amendment precedent. Striking down the Indianapolis ordinance, the Seventh Circuit equated its restrictions to

Murphy, The Value of Pornography, 10 WAyne L. REv. 655, 668 (1964)). Dan White, convicted of voluntary manslaughter for killing San Francisco Mayor George Moscone and Supervisor Harvey Milk, claimed as part of his defense that he was mentally disturbed from eating too many highly sugared products. See Ledbetter, San Francisco Tense as Violence Follows Murder Trial, N.Y. Times, May 23, 1979, at A1, col. 3, A18, col. 3.

Social science research suggests that a plethora of factors other than pornography contribute to violent crime. For example, there is no uniform correlation between the availability of sexual magazines and rape incidence. In one survey of the 50 states and the District of Columbia, which purported to find a statistically significant correlation between consumption of pornography and rape rates, Utah ranked 51st in a sex magazine circulation index but 25th in rape incidence. Missouri was 49th in availability of explicit magazines but 18th in frequency of rape. By contrast, New Hampshire was 44th in its rape rate but 9th in availability of sex magazines. See Lynn, supra note 44, at 93-94. Another study found that the circulation of outdoors magazines-such as Field and Stream-"has a greater correlation with rape rates than the presence of adult theaters." Id. at 95 .

${ }^{220}$ Two Commissioners-Ellen Levine, a journalist, and Dr. Judith Becker, a behavioral scientist-issued a dissenting statement on July 19, 1986:

[I]t is essential to state that the social science research has not been designed to evaluate the relationship between exposure to pornography and the commission of sexual crimes; therefore efforts to tease the current data into proof of a causal link between these acts simply cannot be accepted. Furthermore, social science does not speak to harm, on which this Commission report focuses. Social science research speaks of a relationship among variables or effects that can be positive or negative.

P. Nobile \& E. Nadler, United States of America vs. Sex 310 (1986).

The Meese Commission already has attracted judicial disdain. Although he upheld Dallas's adult establishment ordinance (with minor exceptions), Judge Buchmeyer dismissed "the specious view that pornography 'causes' various social ills and should thus be eliminated." Dumas v. City of Dallas, 648 F. Supp. 1061, 1065 (N.D. Tex. 1986). Judge Buchmeyer charged that "[t]he Meese Commission-which performed no original research-ignored decades of scientific evidence to conclude that pornography 'causes' crime." Id. at 1065 n.12.

221 Final RePORT, supra note 4, at 27.

${ }^{222} I d$. at 349.

${ }^{223}$ See Dumas, 648 F. Supp. at 1065 n.12 ("There is . . judicial recognition that the tenuous link between pornography and crime is not sufficiently established to form the basis of any sound public policy."). 
"thought control."224 The state, Judge Easterbrook concluded, cannot ban speech that conflicts with an "approved" view of women. ${ }^{225}$ Daunted by the prospect of censorship boards, private litigation, governmental civil actions, and, conceivably, police investigations and criminal prosecutions, Professor Thomas Emerson suggests that "[o]ne can hardly expect a system of freedom of expression to flourish under these conditions." ${ }^{226}$ Discursive speech is a risk inherent in a free society. ${ }^{227}$ The harm may be confined to merely involuntary exposure to offensive speech. ${ }^{228}$ The first amendment often acts as a harbor for discord. The danger of antisocial activity did not diminish first amendment protection of advocacy by armed Klansmen of revenge against public officials $^{229}$ nor of student radical challenges to "take the fucking street."230 If these cases did not provide a sufficient threat of lawlessness to justify restriction of speech, no research points sufficiently to harms directly linked to pornography.

The radical feminist position manifests how a denial of free speech "to engineer social change" favoring one segment of the population "erodes the freedoms of all."2s1 The evolution of the videotape market reveals that restriction of pornography distribution would limit rights that women exercise through VGR technology. A feminist anticensorship group, in a Seventh Circuit amicus brief, indicated that "[r]ich fantasy imagery allows us to experience in imagination ways of being we may not wish to experience in real life." ${ }^{232}$ The VGR gives this

${ }^{224}$ American Booksellers Ass'n v. Hudnut, 771 F.2d 323, 328 (7th Cir. 1985), affd mem., 475 U.S. 1001 (1986).

$225 I d$.

${ }^{228}$ Emerson, Pornography and the First Amendment: A Reply to Professor MacKinnon, 3 YAle L. \& PoL'y Rev. 130, 138 (1984).

227 See, e.g., Lynn, supra note 44, at 88-89 ("If the measure of permissible suppression becomes what one or two people might do in response to particular speech, we will all be reduced to sitting in darkened rooms in order to prevent sexual (or other) images from crossing the eyes or mind of someone who could react in an antisocial manner.").

${ }^{228}$ See Erznoznik v. City of Jacksonville, 422 U.S. 205, 209 (1975) ("[W]hen the government, acting as censor, undertakes selectively to shield the public from some kinds of speech on the ground that they are more offensive than others, the First Amendment strictly limits its power."); Cohen v. California, 403 U.S. 15, 24-25 (1971) ("V]erbal tumult, discord, and even offensive utterance . . . are, . . . within established limits, ... . necessary side effects of the broader enduring values which the process of open debate permits us to achieve.").

${ }^{229}$ See Brandenburg v. Ohio, 395 U.S. 444 (1969).

230 Hess v. Indiana, 414 U.S. 105, 107 (1973); see Lynn, supra note 44, at 89 (comparing the protection afforded in Brandenburg and Hess to what would be allowed under the "MacKinnon ordinance").

291 American Rnnksellere Ace'n v Hudnut h0Q F Cunn 12161227 /C N T-d 
fantasy a discreet forum. ${ }^{23 s}$ Consequently, women comprise a significant market for sexually explicit tapes. ${ }^{234}$ To exploit this market, some companies now produce adult videos tailored to a female audience. ${ }^{235}$ Any effort to curtail erotica, some feminists assert, "'delegitimates and makes socially invisible women who find sexually explicit images . . . erotic, liberating or educational'."2se Consequently, antipornography ordinances constitute restriction rather than liberation, in that they constrain a woman's right under the first amendment to watch what she wishes on her VCR.

\section{B. The Private Medium}

More than that of any other electronic medium, the VCR's popularity thrives on privacy. The recorder allows private choice to determine what appears on the television screen; viewing material is chosen individually, not by an intermediary. Use is private and unobtrusive; it occurs primarily in private homes. To that extent, the VGR viewer is in much the same position as Mr. Stanley. Whatever their content, she enjoys her videotapes in a private domain recognized as beyond state regulation.

Legislative support of such privacy rights goes well beyond the narrow reading of Stanley $v$. Georgia. ${ }^{237}$ State constitutions and statutes recognize explicitly an individual's inalienable right to privacy. ${ }^{238}$

ship Taskforce, Amicus Curiae, at 29, American Booksellers Ass'n v. Hudnut, 771 F.2d 323 (7th Cir. 1985)).

${ }^{23 s}$ Pornography need not be relegated to one neighborhood to protect unwilling viewers. The VCR reduces to a minimum the number of individuals who share the fantasy-or are even aware of it.

${ }_{234}$ A nationwide survey of 1000 stores that stock adult videos found that women or couples rent $63 \%$ of such tapes. See Dullea, X-Rated Couples' Films Finding a New Market, N.Y. Times, Oct. 6, 1986, at B12, col. 2, B12, col. 3. Women now account for an estimated 40 million annual rentals of X-rated videos. See Leo, Romantic Porn in the Boudoir, TIME, Mar. 30, 1987, at 63, 63.

${ }^{235}$ Adult videotapes catering to women are likely to feature more plot development than is usual for X-rated material, which has traditionally been one-dimensional. See Leo, supra note 234 , at 63 . There is also a greater emphasis on romantic presentation. As one video company public-relations director has explained, "We go for the pretty-pretty clothes, lingerie, lacquered fingernails, hair and makeup by stylists.' 'We want the women viewers, after all[]'. . . 'More and more women are expressing a desire to see erotica, so you'll see much more romantic lovemaking than in the past'." Dullea, supra note 234 , at B12, cols. 5-6. 
The Privacy Act of $1974^{239}$ sets the standard for compilation of personal information by the federal government and establishes procedures for access to that information. This protection extends to new communication technology. State legislators have proscribed the use of cable's two-way capacity to eavesdrop on subscriber residences. ${ }^{240}$ Beyond the formal legislative level, lawmakers remain conscious of privacy concerns. These concerns were central to the forces that led to the rejection of Judge Robert Bork's appointment to the Supreme Court. ${ }^{241}$ This recognition of the "right to be let alone"242 can serve as a foundation for the constitutional protection of videotape viewing.

The viewer privacy inherent in the medium lends credence to a dissenting theory running through the post-Stanley privacy decisions. The right to enjoy material in private is meaningless without a concurrent right to acquire information. One federal district court reasoned that if an individual has a right to receive and possess obscene material, "then someone must have the right to deliver it to him."243 Likewise, Justice Blackmun, dissenting in the same case on review, concluded that the right to possess "is hollow indeed" without the right to carry it outside the home. ${ }^{244}$ This position recognizes that the first amendment "right to receive ideas that are unfettered by government interference

otherwise provided herein."); MAss. ANN. LAws ch. 214, § 1B (Law. Co-op. 1986) ("A person shall have a right against unreasonable, substantial or serious interference with his privacy.").

${ }^{239} 5$ U.S.C. § 552a (1982 \& Supp. IV 1986).

240 Cal. Penal Code $\S 637.5$ (West Supp. 1988); Ill. ANN. Stat. ch. 38, para. $87-3, \S 3(a)$ (Smith-Hurd Supp. 1987).

${ }_{241}$ See Greenhouse, What Went Wrong, N.Y. Times, Oct. 7, 1987, at B10, col. 1, B10, col. 3 ("The issue that jelled for the opposition, suprisingly, was privacy. The number of senators, both on and off the Judiciary Committee, who gave prominence to the privacy issue in their speeches opposing Judge Bork was striking."). It is ironic that during his confirmation hearings, Judge Bork's supporters championed him in a way that further demonstrates the widespread concern for personal privacy, especially as it relates to the subject of this Comment. Members of the Senate Judiciary Committee criticized a Washington, D.C. weekly for publishing a list of 146 videos rented by Judge Bork or people in his home. See Editorial, Wash. Post, Sept. 30, 1987, at A18, col. $1, \mathrm{~A} 18$, col. 1 . In the wake of these hearings, some Congressmen advocate legislative restrictions on disclosure of video-rental records. See Hinds, Personal but Not Confidential: A New Debate over Privacy, N.Y. Times, Feb. 27, 1988, at 56, col. 1, 56, col. 1. (1890).

${ }^{212}$ See Warren \& Brandeis, The Right to Privacy, 4 Harv. L. Rev. 193, 193

243 Unpublished opinion of the United States District Court for the Central District of California, quoted in United States v. Reidel, 402 U.S. 351, 355 (1971). The Court reversed, holding that this reading of Stanley was too broad. Reidel, 402 U.S. at 355; see also Marks v. United States, 430 U.S. 188, 198 (1977) (Stevens, J., concurring in part \& dissenting in part) ("[T]he statute is predicated on the somewhat illogical premise that a person may be prosecuted criminally for providing another with material he has a constitutional right to possess.").

${ }^{244}$ Reidel, 402 U.S. at 381 (Black, J., dissenting). 
[does not] change[] when individuals . . . receive ideas from the electronic media instead of the print media." ${ }^{245}$ The VCR's immense popularity derives, in part, from the privacy of its predominant use. This use should shape the resulting first amendment standard.

\section{The Twentieth-Century Handbill}

First amendment analysis must account for the VCR's status as more than a variation of television. VCR technology does not lend itself to the scarcity and intrusion justifications given for the regulation of broadcast content. The scarcity rationale is inappropriate: "choice in video cassette programming is completely determined by what the consumer is willing to spend for software."246 Like the cable viewer, the VGR user makes an affirmative content choice; the risk of offending an unwilling viewer is minimal. ${ }^{247}$ Like the cable audience, the fragmented VCR audience is not subject to a pervasive and intrusive signal; there is no captive audience. ${ }^{248}$ VCR viewing does not constitute interstate communication by wire or radio, the jurisdictional precondition for FGC regulation. ${ }^{249}$ VGR technology produces speech that is unique in the electronic media.

The videotape currently plays a prominent role in communication. It has allowed both viewer and speaker to exert unprecedented control over the powerful television medium. One can now reach the other without a broadcast intermediary. This allows for personal communication never achieved through national broadcasting. In entertainment programming, videotape producers take advantage of this characteristic by "narrowcasting." 250 In organizational communications, the videotape emerges as a more powerful newsletter. ${ }^{261}$ Videotapes even have a role to play in government: they have been used to describe the legislative process, ${ }^{262}$ explain tax legislation, ${ }^{253}$ and resolve a prison hostage

${ }^{215}$ In re Complaint of Syracuse Peace Council Against Television Station WTVH, 2 F.C.C. Rec. 5043, 5057 (1987).

${ }^{216}$ Fowler \& Brenner, supra note 91, at 226.

247 See Lynn, supra note 44, at 113.

248 See Geller \& Lampert, supra note 85, at 623 n.127 ("captive audience" concept applies less to cable than to broadcasting because cable viewers pay to have programming brought into the home).

24947 U.S.C. § 152(a) (1982 \& Supp. III 1985).

250 See supra notes 161-67 and accompanying text.

${ }_{201}$ See, e.g, Krier, Video Technology Rallies Striking United Pilots, L.A. Times, May 24, 1985, \& V, at 1, col. 1, 22, col. 1 (In a 1985 strike by United Airlines pilots, both management and the union communicated with the widely dispersed strikers through videotapes.).

${ }_{232}$ The California State Senate, in an effort to improve its image, produced an $\$ 80,000$ videotape describing the legislative process. The video is the modernized suc- 
crisis. ${ }^{254}$ With VCR technology, one individual can use a little black box to convey virtually any message to another.

The VGR also has expanded the marketplace of ideas. It has filled voids that broadcast speech overlooked by serving discrete interests that had been neglected. ${ }^{255}$ The videotape industry warrants broad first amendment protection because it has become an important information medium. In that respect, a videotape is much like a book. Similar legal protection may prompt recognition that ours is becoming a video-dominated society. ${ }^{258}$ The speakers understand this. Political campaigns are "changing to accommodate the way people are now getting their information." 257 Whether you characterize the first amendment's purpose as the fostering of a marketplace of ideas ${ }^{258}$ or ensuring an informed debate, ${ }^{259}$ the videotape proliferation furthers this goal. An erosion of the distinction between broadcast and print allows the first amendment to

cessor to a "remarkably dull pamphlet." Ingram, State Senate Works on Its Image, L.A. Times, Nov. 19, 1986, § I, at 27, col. 1, 27, col. 3.

${ }^{263}$ The Internal Revenue Service recently produced two basic "how-to" videotapes: "Tax Forms 1986" and "How to Prepare IRS Form W-4." See Sloane, supra note 172 , at 34 , col. 1 .

${ }^{254}$ Videotapes were used to communicate with Cuban prisoners who rioted in southern prisons. Attorney General Meese prepared a tape offering to postpone the planned deportations of prisoners if hostages were released without delay. See Cubans Seize Atlanta Prison, Take 75 Hostage, Phila. Inquirer, Nov. 24, 1987, at A1, col. 1, A1, col. 2. The standoff in Oakdale, Louisiana, ended after the prisoners were assured in a videotape prepared by a Miami bishop that they could trust government statements in the negotiations. See Cuban Inmates in Louisiana Free All 26 Hostages, N.Y. Times, Nov. 30, 1987, at A1, col. 1, A1, col. 1.

${ }^{255}$ For example, the videotape market has spurred the production of animated movies, which had declined because of high production costs. The home viewing market prompted Walt Disney productions to accelerate its animated movie production schedule from one every three to four years to one every 18 months. See Harmetz, supra note 161 , at 19 , col. 1 .

${ }^{256}$ Even the harshest critics of this trend recognize its historical significance. See, e.g., A. Bloom, The Closing of The American Mind 59 (1987) ("With great subtlety and energy, television enters not only the room, but also the tastes of old and young alike, appealing to the immediately pleasant and subverting whatever does not conform to it. Nietzsche said the newspaper had replaced the prayer in the life of the modern bourgeois, meaning that the busy, the cheap, the ephemeral, had usurped all that remained of the eternal in his daily life. Now television has replaced the newspaper."); see also Yarrow, Video Cassettes Pushing Books off Shelves, N.Y. Times, Feb. $22,1988, \S$ III, at C13, col. 1, C13, col. 1 (detailing the evolution of home video libraries).

257 See Lindsey, supra note 177, at D 24, col. 3; see also supra notes 173-78 and accompanying text (discussing use of video cassettes to publicize political views).

${ }^{258}$ See Baker, Scope of the First Amendment Freedom of Speech, 25 UCLA L. REv. 964, 964 (1978) ("The classic marketplace of ideas model argues that truth . . . can be discovered through robust debate, free from governmental interference.").

258 See A. Meiklejohn, Political Freedom 75 (1960) (The primary purpose of the first amendment is to educate so that citizens may "understand the issues which bear upon our common life."). 
serve its function in a new milieu. Failure to acknowledge technological reality could render the first amendment obsolete.

\section{CONCLUSION}

The VGR does not fit traditional broadcasting regulation designed for television and radio, because it resembles the print media more closely. The VCR is more than a television or movie screen; the video cassette also acts as a how-to manual, an advertising supplement, and a political leaflet. Although it employs broadcast technology, the VCR lacks those elements that historically restricted broadcasters' first amendment rights. The video cassette neither makes use of a limited airwave spectrum, nor is it a pervasive influence intruding on unwilling viewers. The waning of the fairness doctrine and enhanced first amendment protection of cable television indicate that the constitutional protection of broadcast media is moving closer to print standards. The VGR furthers this transition. Its low production costs and its versatility make the recorder an important information source, one that offers the possibility of communication through television without a middleman in the form of a network, broadcast licensee, or cable company. ${ }^{260}$ This versatility, combined with the VCR's predominantly private use, should qualify the VCR and its storage medium, the videotape, with the constitutional protections of the print media. The VCR warrants such broad protection because it marks a triumph for the marketplace of ideas. That triumph is one the first amendment should nurture. 